\title{
The Role of the Pharmacist in Patient Care (Book Review)
}

\section{B.K. Khanam}

Dr. M. Nasirullah Memorial Trust, Tejgaon, Dhaka 1215, Bangladesh

*Corresponding Author: Khanam, Chairman, Dr. M. Nasirullah Memorial Trust, Tejgaon, Dhaka 1215, Bangladesh. E-mail: dr.m.nasirullah.trust@gmail.com

Received Date: January 22, 2021; Accepted Date: February 26, 2021; Published Date; March $10,2021$. Citation: B.K. Khanam, The Role of the Pharmacist in Patient Care (Book Review), J. Clinical Research Notes. 2(1). Doi: 10.31579/26908816/031.

Copyright: (C) 2021 B.K. Khanam, This is an open-access article distributed under the terms of the Creative Commons Attribution License, which permits unrestricted use, distribution, and reproduction in any medium,provided the original author and source are credited.

\section{Abstract}

Most people on the outside of the health care profession are not familiar with this new role of the pharmacist. The general public has created a stereotypical pharmacist's picture as being a person who stands behind a counter, dispenses medicine with some instructions to the respective consumer. Pharmacy practice has changed substantially in recent years. Today's pharmacists have unique training and expertise in the appropriate use of medications and provide a wide array of patient care services in many different practice settings. As doctors are busy with the diagnosis and treatment of patients, the pharmacist can assist them by selecting the most appropriate drug for a patient. Interventions by the pharmacists have always been considered as a valuable input by the health care community in the patient care process by reducing the medication errors, rationalizing the therapy and reducing the cost of therapy. The development and approval of the Pharmacists' Patient Care Process by the Joint Commission of Pharmacy Practitioners and incorporation of the Process into the 2016 Accreditation Council for Pharmacy Education Standards has the potential to lead to important changes in the practice of pharmacy, and to the enhanced acknowledgment, acceptance, and reimbursement for pharmacy and pharmacist services. As an author, it is my heartiest believe that the book will adjoin significant apprehension to future pharmacists in patient care as most of the portion created from recently published articles focusing pharmacists in patient care settings.

Keywords: patient care; patient compliance; patient counseling; extemporaneous prescription compounding; framework for medication safety; patient behavior; patient education; patient-provider relationship; patient relationship management; patient problem solving and preventive care; pharmacovigilance; patient safety; pharmaco-economics; longterm care; community liaison pharmacists in home care; pharmacists in ambulatory care; critical care pharmacists; rational use of drugs; surgical dressing; medication risk management; medication history taking and reconciliation; drug related problems; medication reconciliation; palliative and hospice care
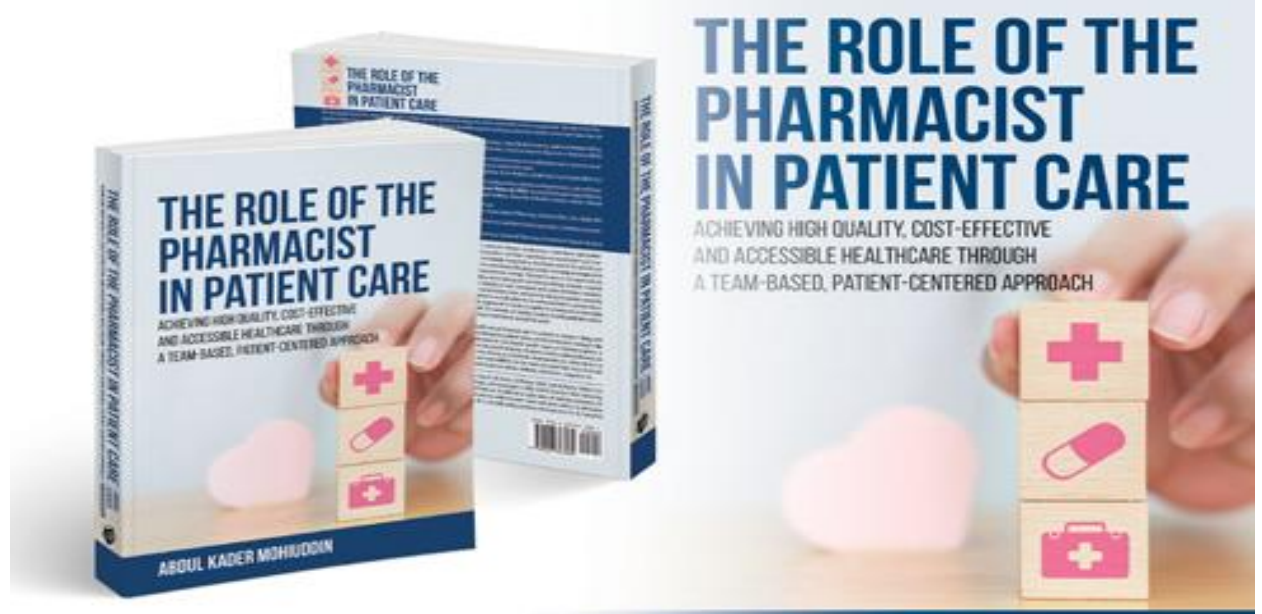

ABDUL KADER MOHIUDDIN

Figure 1. Book Cover Page. [Publisher: Universal-Publishers (US). (ISBN-10: 1627343083, ISBN-13: 9781627343084)] 


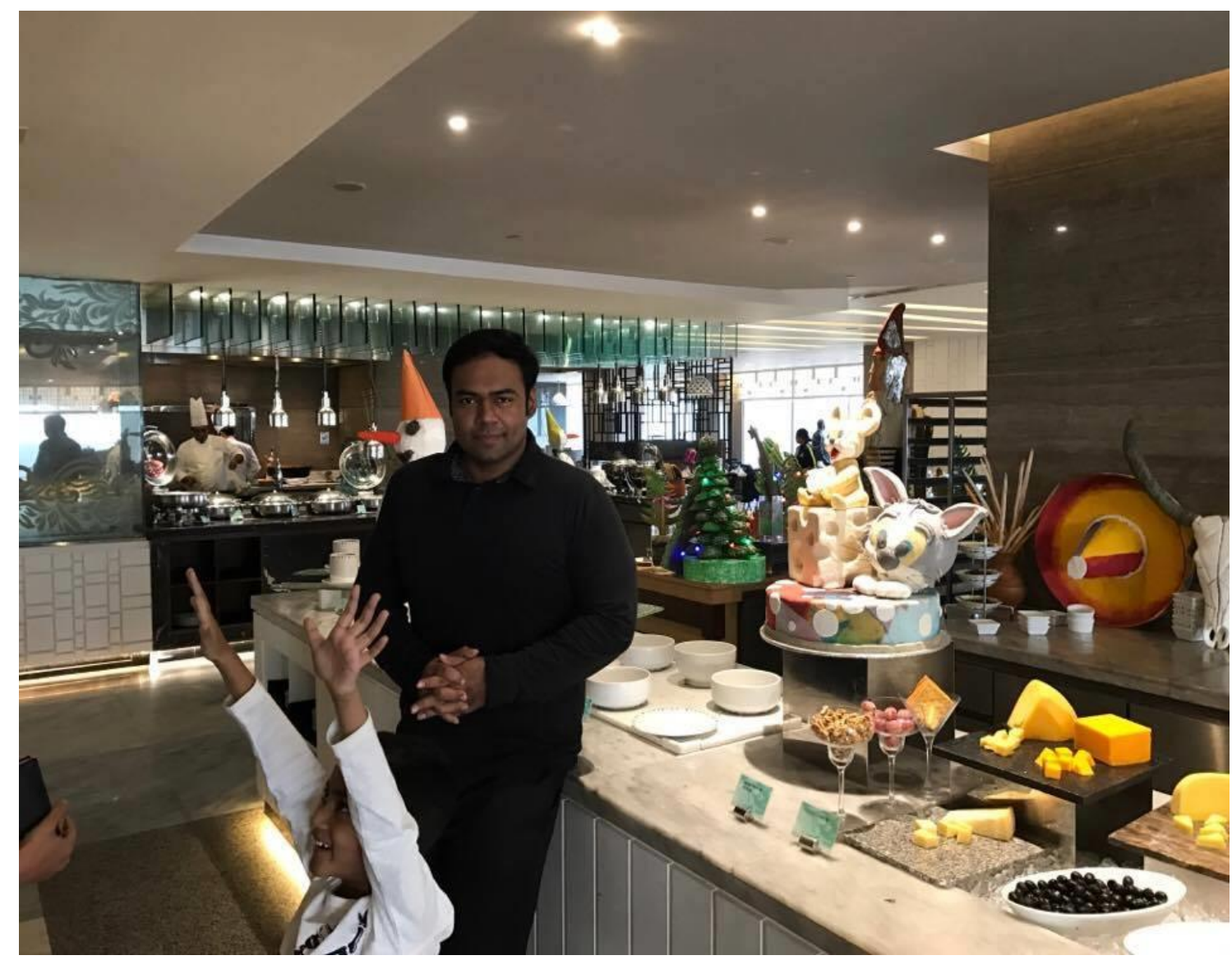

Figure 2. The Author

\section{Introduction}

The goal of high quality, cost-effective and accessible health care for patients is achieved through team-based patient-centered care. Pharmacists are essential members of the health care team. The profession of pharmacy is continuing its evolution from a principal focus on medication product distribution to expanded clinically-oriented patient care services. As a result of this professional evolution, the importance of, and need for, a consistent process of care in the delivery of patient care services has been increasingly recognized by the profession at large. Pharmacists in hospital, community care, dispensing and allied healthcare arena are highly appreciated for their knowledge-based contribution and dedication towards profession. The purpose of the book is to guide the patient care pharmacists in their day to day activities. Along with guidelines, the book encloses ideas about patient dealing, patient rights, ethical decision making and professionalism. At every chapter, the role of pharmacists in that chapter specific issues are detailed explicitly so that a professional pharmacist or a student can figure out his or her do's and not to do's in that specific situations. Moreover, further reading references are listed to follow guidelines further. So, the book is an archive of potential references too. Among so many books on clinical pharmacy, hospital and community care pharmacy the role of pharmacists in patient care is rarely highlighted with a very little information. The sector is emerging in both developed and under-developed countries. In most of the books, either doctors' or nurses' roles are highlighted. The proposed book (Figure 1) highlights pharmacists' roles and responsibilities to the most, separated from those of doctors and nurses, with most recent information obtained from recently published articles of several journals, books, newsletters, magazines etc. The book's chapter-based summary is added in Table 1 and comparison with similar other available books given in Table 2.

\section{Pharmacist's Role in Patient Care}

The development and approval of the Pharmacists' Patient Care Process by the Joint Commission of Pharmacy Practitioners and incorporation of the Process into the 2016 Accreditation Council for Pharmacy Education Standards has the potential to lead to important changes in the practice of pharmacy, and to the enhanced acknowledgment, acceptance, and reimbursement for pharmacy and pharmacist services [1]. Nowadays, pharmacists also ensure the rational and cost-effective use of medicines, promote healthy living, and improve clinical outcomes by actively engaging in direct patient care and collaborating with many healthcare disciplines. With this expanding scope of practice, pharmacists are being recognized as key components in providing individualized patient care as part of interprofessional healthcare teams [2]. Pharmacists help manage complex patients because they look at medications with a different eye than a doctor. One important practice they perform is a "comprehensive medication review" where patients bring in medications, vitamins, supplements, and OTC drugs [3]. Nowadays, the shortage of health personnel, and in particular pharmacists, is a challenging issue that the health systems have to face. The use of a new technology such as tele pharmacy can represent a possible option to solve these problems [4]. Up to $50 \%$ of $\mathrm{ADE}$ and ADE-related hospitalizations are judged to be preventable by avoiding inappropriate prescribing. Use of a simple interdisciplinary medication review has been shown to lead to the reduction of inappropriate prescribing and costs, but there was no effect on clinically relevant patient outcomes, possibly due to a lack of power and insufficient observation time [5]. Pharmacists see their patients somewhere between 1.5 and 10 times more frequently than they see primary care physicians [6]. Clinical pharmacists can help patients manage their medicines and reduce their anxiety about taking multiple 
medicines [7]. Pharmacists also get benefit because there is an increased recognition and respect for the value of the advice and service that they provide [8]. There is a need to increase access to primary care services, control costs, and improve outcomes in health care for patients especially in the management of chronic conditions which puts a strain on health care systems worldwide [9]. Pharmacists' better access to the patients and their acceptability improve patient care by enabling pharmacists to play an even greater role in the provision of safe and effective unscheduled care, treating common clinical conditions and responding to emergency requests for medicines [10]. Therefore, students who are interested in patient care practice as their future career, should develop a standardized approach to assessing, prioritizing, and resolving drug-related problems such as untreated conditions, appropriate drug selection, duplication of therapy, use of drugs without a condition or indication, over- or underdosing, adverse effects or toxicity, allergic reactions, drug interactions, adherence, availability and access, cost, and outcomes expectations. Students also should be looking for the beneficial outcomes of drug therapy and pharmacy services with respect to patient understanding, disease and disorder prevention, and medication-associated efficacy and safety.

\begin{tabular}{|c|c|}
\hline Chapter & Synopsis \\
\hline Chapter 1. & $\begin{array}{l}\text { Pharmacy Practice at a Glance } \\
\text { Pharmacy is the art and science of preparing and dispensing medications and the provision of drug-related } \\
\text { information to the public. It involves the interpretation of prescription orders; the compounding, labeling, } \\
\text { and dispensing of drugs and devices; drug product selection and drug utilization reviews; patient } \\
\text { monitoring and intervention; and the provision of cognitive services related to use of medications and } \\
\text { devices. The current philosophy or approach to professional practice in pharmacy is designated as } \\
\text { pharmaceutical care. This concept holds that the important role of the pharmacist is "the responsible } \\
\text { provision of drug therapy for the purpose of achieving definite outcomes that improve a patient's quality } \\
\text { of life." Pharmacists, then, are those who are educated and licensed to dispense drugs and to provide drug } \\
\text { information- they are experts on medications. They are the most accessible member of today's health care } \\
\text { team, and often are the first source of assistance and advice on many common ailments and health care } \\
\text { matters. }\end{array}$ \\
\hline Chapter 2. & $\begin{array}{l}\text { Pharmacists in Clinical Pharmacy Practice } \\
\text { Clinical pharmacy took over an aspect of medical care that had been partially abandoned by physicians. } \\
\text { Overburdened by patient loads and the explosion of new drugs, physicians turned to pharmacists more and } \\
\text { more for drug information, especially within institutional settings. Once relegated to counting and pouring, } \\
\text { pharmacists headed institutional reviews of drug utilization and served as consultants to all types of health- } \\
\text { care facilities. A comparison of Part I of this current edition of this text with previous editions will reveal } \\
\text { the unprecedented expansion of opportunities for pharmacists in recent times. }\end{array}$ \\
\hline \multirow[t]{2}{*}{ Chapter 3.} & $\begin{array}{l}\text { Pharmacists in Hospital Management } \\
\text { The advancements in medicine and technology have allowed care that once required the intensive care of } \\
\text { a hospital setting to be delivered in less intensive settings. As a result, we have witnessed the development } \\
\text { of ambulatory surgery centers, skilled nursing facilities, home health services, outpatient treatment centers, } \\
\text { and multiple chronic disease monitoring programs. Health care leaders continually search for the delivery } \\
\text { model that meets the quality, safety, and access expectations of patients at }\end{array}$ \\
\hline & $\begin{array}{l}\text { an affordable cost. This quest led to a progression from individual stand-alone hospitals to health systems. } \\
\text { These "health systems" include the acute care services that only hospitals are equipped to provide and a } \\
\text { cadre of other services that may include primary care, specialty outpatient care, home care, nursing home } \\
\text { facilities, hospice care, ambulatory surgery programs, }\end{array}$ \\
\hline Chapter 4. & $\begin{array}{l}\text { Pharmacists in Community Care } \\
\text { Community pharmacy comprises all of those establishments that are privately owned and whose function, } \\
\text { in varying degrees, is to serve society's need for both drug products and pharmaceutical services. It is } \\
\text { difficult to characterize or describe the typical pharmacy because of the great variance among them. They } \\
\text { range from the corporately owned chain pharmacy, to the pharmacy department in a supermarket, to the } \\
\text { independently owned pharmaceutical center that provides prescription service plus a relatively few lines } \\
\text { of health-related products. Although heterogeneous in some respects, as in type of ownership and type of } \\
\text { goods and services offered, community pharmacies generally are recognized by the public as the most } \\
\text { accessible source of drugs and of information about drugs. }\end{array}$ \\
\hline Chapter 5. & $\begin{array}{l}\text { Patient Rights and Ethical Care } \\
\text { Patients also have a right to treatment that is both safe and effective within given parameters. The } \\
\text { fundamental question that must be posed prior to considering any medical or surgical treatment for a patient } \\
\text { is, Is the treatment safe and effective? Such a legal standard for drugs has been in effect since the passage } \\
\text { of federal legislation in the early part of the } 20 \text { th century. Not only must a drug be shown to be effective- } \\
\text { that is, able to produce the effect for which it was administered-it must work with a certain degree of } \\
\text { safety. Patients generally choose their own physician, pharmacy, and hospital. Patients are allowed to } \\
\text { choose from multiple options of treatment when they exist. Patients must give their approval, through the } \\
\text { process of informed consent, prior to the initiation of care. All of the preceding presupposes that treatment } \\
\text { is available and that the patient has the economic wherewithal to pay for that treatment. For patients who } \\
\text { are uninsured or lack the ability to pay, the right to choose the nature of their health care is meaningless. }\end{array}$ \\
\hline Chapter 6. & Prescription \\
\hline
\end{tabular}




\begin{tabular}{|c|c|}
\hline & $\begin{array}{l}\text { The prescription order is a part of the professional relationship among the prescriber, the pharmacist, and } \\
\text { the patient. It is the pharmacist's responsibility in this relationship to provide quality pharmaceutical care } \\
\text { that meets the medication needs of the patient. The pharmacist must be precise in the manual aspects of } \\
\text { filling the prescription order and must provide the patient with the necessary information and guidance to } \\
\text { assure the patient's compliance in taking the medication properly. It is also the pharmacist's responsibility } \\
\text { to advise the prescriber of drug sensitivities the patient may have, previous adverse drug reactions (ADRs), } \\
\text { and/or other medications that the patient may be taking that may alter the effectiveness or safety of the } \\
\text { newly or previously prescribed medications. Pharmacists now find themselves frequently contacting } \\
\text { physicians to suggest alternative drug products for individual patients as dictated by the formularies used } \\
\text { by third-part prescription insurance plans. To meet these responsibilities, it is essential that the pharmacist } \\
\text { maintains a high level of practice competence, keeps appropriate records on the health status and } \\
\text { medication history of his/her patients and develops professional working relationships with other health } \\
\text { professionals. }\end{array}$ \\
\hline \multirow[t]{2}{*}{ Chapter 7.} & $\begin{array}{l}\text { Prescribing } \\
\text { While drugs have the capacity to enhance health, they all have the potential to cause harm if prescribed } \\
\text { inappropriately. For this reason, it is recommended that healthcare }\end{array}$ \\
\hline & $\begin{array}{l}\text { professionals who prescribe medications exercise critical thinking skills to ensure the safe and effective } \\
\text { use of therapeutic agents. Pharmacists have crucial role plays in both handling prescription and prescribing. } \\
\text { A rational prescribing is the sole of patient safety, compliance and patient relief. This paper proposes aims } \\
\text { that a prescriber should try to achieve, both on first prescribing a drug to maximize effectiveness, minimize } \\
\text { risks and costs, and respect the patient's actual need. }\end{array}$ \\
\hline Chapter 8. & $\begin{array}{l}\text { Patient Counseling } \\
\text { Patient have an altered mental state mostly driven by emotional disturbance for being ill. Along with that } \\
\text { cultural and economic factors gives rise to a question of out of the pocket expense. Any counseling or } \\
\text { consultation provided should be done in a manner which respects the patient's privacy and maintains } \\
\text { confidentiality. Nothing should be taken for granted regarding the patient's understanding of how to use } \\
\text { medication, and appropriate steps must be taken to provide patients with the information and counseling } \\
\text { necessary to use their medications as effectively and as safely as possible. }\end{array}$ \\
\hline Chapter 9. & $\begin{array}{l}\text { Extemporaneous Prescription Compounding } \\
\text { Pharmacy activities to individualize patient therapy include compounding and clinical functions. Either } \\
\text { function in the absence of the other results in placing pharmacy in a disadvantaged position. It is important } \\
\text { to use a pharmacist's expertise to adjust dosage quantities, frequencies, and even dosage forms for } \\
\text { enhanced compliance. All pharmacists should understand the options presented by compounding. } \\
\text { Pharmaceutical compounding is increasing for a number of reasons, including the availability of a limited } \\
\text { number of dosage forms for most drugs, a limited number of strengths of most drugs, home health care, } \\
\text { hospice, the non-availability of drug products/combinations, discontinued drugs, drug shortages, orphan } \\
\text { drugs, new therapeutic approaches and special patient populations (pediatrics, geriatrics, bioidentical } \\
\text { hormone replacement therapy for postmenopausal women, pain management, dental patients, } \\
\text { environmentally and cosmetic sensitive patients, sports injuries and veterinary compounding). }\end{array}$ \\
\hline Chapter 10. & $\begin{array}{l}\text { Framework for Medication Safety } \\
\text { Appropriate medication use is a complex process involving multiple organizations and professions from } \\
\text { various disciplines combined with a working knowledge of medications, access to accurate and complete } \\
\text { patient information and integration of interrelated decisions over a period of time. The growing complexity } \\
\text { of science and technology requires health care providers to know more, manage more, monitor more, and } \\
\text { involve more care providers than ever before. Current methods of organizing and delivering care are not } \\
\text { able to meet the new expectations of patients and families because the knowledge, skills, care options, } \\
\text { devices, and medications have advanced more rapidly than the health care system's ability to deliver them } \\
\text { safety, effectively, and efficiently. The potential for errors of omission or commission to creep into the } \\
\text { process is extraordinary. No one clinician can retain all the information necessary for overseeing sound, } \\
\text { safe, best practice. This is especially true in the case of pharmaceutical delivery and development. }\end{array}$ \\
\hline \multirow[t]{2}{*}{ Chapter 11.} & $\begin{array}{l}\text { The Enigma of Patient Behavior } \\
\text { Patients today are considered to be thinking, able decision makers who can play an important role in the } \\
\text { treatment process. Because patients are now recognized as active individuals, more attention is being paid } \\
\text { to ways of restoring health or slowing illness progression through improved provider-patient } \\
\text { communication and patients' involvement in their own treatment. Emphasis therefore is placed on a range } \\
\text { of patient treatment behaviors including sharing beliefs and expectations, asking questions, adhering to } \\
\text { regimens, using home monitoring devices, keeping appointments, }\end{array}$ \\
\hline & $\begin{array}{l}\text { identifying and reporting side effects and drug-taking problems, and other valuable forms of } \\
\text { communication that are necessary in contemporary health care. }\end{array}$ \\
\hline Chapter 12. & $\begin{array}{l}\text { Patient Education } \\
\text { Patient education ensures that healthcare team is working together on patients' individual medication plan, } \\
\text { in conjunction with the rest of treatment, is vital to your recovery. Medication management is part of every } \\
\text { patient's plan of care. On an initial visit a clinician completes comprehensive medication reconciliation. }\end{array}$ \\
\hline
\end{tabular}




\begin{tabular}{|c|c|}
\hline & $\begin{array}{l}\text { However, education is provided to every patient based on each medication the patient is prescribed. This } \\
\text { includes its purpose, how and when to take it and how much of the medication to take. Education may be } \\
\text { provided by any healthcare professional who has undertaken appropriate training education, education on } \\
\text { patient communication and education is usually included in the healthcare professional's training. Health } \\
\text { education is also a tool used by managed care plans, and may include both general preventive education or } \\
\text { health promotion and disease or condition specific education. Important elements of patient education are } \\
\text { skill building and responsibility: patients need to know when, how, and why they need to make a lifestyle } \\
\text { change. Group effort is equally important: each member of the patient's health care team needs to be } \\
\text { involved. }\end{array}$ \\
\hline Chapter 13. & $\begin{array}{l}\text { Patient-Provider Relationship } \\
\text { The Provider-Patient Relationship is a recent idea of medicinal human science in which patients } \\
\text { intentionally approach a specialist and, in this way, turn into a piece of an agreement in which they will in } \\
\text { general reside with the specialist's direction. It has been recommended that a perfect relationship has } \\
\text { specifically deliberate decision, professional's capability, great correspondence, compassion by the } \\
\text { specialists, congruity, and no irreconcilable circumstance. Truth be told, a poor relationship has been turned } \\
\text { out to be a noteworthy impediment for the two specialists and patients, and has in the end influenced the } \\
\text { nature of medicinal services and capacity of the patients to adapt to their disease. Inferable from poor } \\
\text { relationship, patients do not demonstrate consistence with specialist guidance totally; pick expert - by } \\
\text { changing their professional over and over; stay on edge; may pick quacks or other non-logical types of } \\
\text { treatment; critical increment in immediate and roundabout restorative costs. In view of intermittent change } \\
\text { in line of treatment according to the counsel of various expert and non-culmination of the whole course of } \\
\text { medications, there is an unmistakable extension for the rise of antimicrobial opposition, which further } \\
\text { intensifies the medicinal expense and tension, lastly may create genuine types of malady or complexities. } \\
\text { From the professionals' point of view, they may request superfluous examinations or may give over- } \\
\text { medicines, as a sanity check. There is likewise watched an amazing decrease in human touch or sympathy; } \\
\text { and a noteworthy ascent in unfortunate rivalry among specialists. }\end{array}$ \\
\hline \multirow[t]{2}{*}{ Chapter 14.} & $\begin{array}{l}\text { Patient Compliance } \\
\text { With regard to the provision of health care, the concept of compliance can be viewed broadly, as it relates } \\
\text { to instructions concerning diet, exercise, rest, return appointments, etc., in addition to the use of drugs. } \\
\text { However, it is in discussions concerning drug therapy that the designation patient compliance is employed } \\
\text { most frequently. It is in this context that it will be used in this discussion, and compliance can be defined } \\
\text { as the extent to which an individual's behavior coincides with medical } \\
\text { or health instructions/advice. Compliance with therapy implies an understanding of how the medication is } \\
\text { to be used, as well as a positive behavior in which the patient is motivated sufficiently to use the prescribed } \\
\text { treatment in the manner intended, }\end{array}$ \\
\hline & $\begin{array}{l}\text { because of a perceived self-benefit and a positive outcome (e.g., enhanced daily functioning and well- } \\
\text { being). }\end{array}$ \\
\hline Chapter 15. & $\begin{array}{l}\text { Patient Relationship Management } \\
\text { In the healthcare sector the key customers are patients. Hospitals may offer better care by establishing a } \\
\text { long-term relationship between the hospital and a patient. The primary reason for investing in building } \\
\text { positive relationships with patients is a limited number of patients in the therapeutic segment or of long- } \\
\text { term care and only clinics aware of this fact that can attach to each patient have a chance to build a } \\
\text { sustainable advantage. Encouragement of the patient to continue to use the services of a company/provider } \\
\text { is a procedure several times cheaper than getting new patients. Developed or under developed country, } \\
\text { patients have a similar need for understanding and following treatment guidelines which is truly impractical } \\
\text { for long term care without personal supervision. So many factors are behind patient relationship but one } \\
\text { thing clearly understood that the handling of such situation is a provider's function, a regular follow up } \\
\text { through taking different measures along with treatment intervention. }\end{array}$ \\
\hline Chapter 16. & $\begin{array}{l}\text { Patient Problem Solving and Preventive Care } \\
\text { Pharmaceutical care is a straightforward concept. It involves the pharmacist working in concert with his/her } \\
\text { patients and other healthcare providers to identify, monitor, and achieve desirable health-related outcomes } \\
\text { through the appropriate use of medications. The care provided must be based upon a logical, effective, and } \\
\text { patient-specific pharmaceutical care plan. There is an old saying, "an ounce of prevention is worth a pound } \\
\text { of cure." This has never been true in health care. Routine follow-up with primary care physicians and other } \\
\text { health care professionals can aid in the early detection of many medical conditions (e.g., cancer, diabetes, } \\
\text { hypertension) and can encourage healthy habits that prevent the development of other conditions (e.g., } \\
\text { Hormone replacement therapy, substance abuse, obesity prevention, thyroid disorders etc.). }\end{array}$ \\
\hline Chapter 17 & $\begin{array}{l}\text { Pharmacovigilance } \\
\text { Pharmacovigilance fundamentally comprises safety of prescription. It is the science and movement } \\
\text { associated with collection, detection, assessment, monitoring, and counteractive action of untoward } \\
\text { impacts with pharmaceutical items. Drug specialists have entered job in wellbeing frameworks to keep up } \\
\text { the objective and safe utilization of medication for they are sedate specialists who are unequivocally } \\
\text { prepared in this field. The perspective of drug store understudies on pharmacovigilance and ADR }\end{array}$ \\
\hline
\end{tabular}




\begin{tabular}{|c|c|}
\hline & $\begin{array}{l}\text { announcing has additionally been talked about with a mean to center the need to improve content identified } \\
\text { with ADR revealing and pharmacovigilance in undergrad drug store educational programs. Globally, } \\
\text { despite the fact that the job of drug specialists inside national pharmacovigilance frameworks varies, it is } \\
\text { exceptionally all around perceived. Reconciliation of ADR detailing ideas in instruction educational } \\
\text { programs, preparing of drug specialists and willful commitment of drug specialists in ADR announcing is } \\
\text { essential in accomplishing the safety objectives and preservation of general wellbeing. Additionally, these } \\
\text { learning holes can be placated through ceaseless expert improvement projects and reinforcing hypothetical } \\
\text { and viable information in undergrad drug store educational programs. Without adequately recognizing and } \\
\text { acknowledging preparing requirements of drug specialists and other social insurance experts, the ability of } \\
\text { national pharmacovigilance frameworks is probably not going to enhance which may trade off patient's } \\
\text { safety. }\end{array}$ \\
\hline \multirow[t]{2}{*}{ Chapter 18} & Patient Safety \\
\hline & $\begin{array}{l}\text { Patient safety is a global concern and is the most noteworthy areas of medicinal services quality. Medical } \\
\text { error is a noteworthy patient safety concern, causing increment in medicinal services cost because of } \\
\text { mortality, morbidity, or broadened clinic remain. A definition for patient safety has emerged from the } \\
\text { medicinal services quality development that is similarly unique, with different ways to deal with the more } \\
\text { solid basic segments. Patient safety was characterized as "the counteractive action of damage to patients." } \\
\text { Importance is put on the arrangement of consideration conveyance that blocks errors; gains from the errors } \\
\text { that do happen; and is based on a culture of safety that includes medicinal services experts, associations, } \\
\text { and patients. Patient safety culture is a multifaceted marvel. Patient safety culture appraisals, required by } \\
\text { universal accreditation associations, enable services associations to acquire an unmistakable perspective } \\
\text { of the patient safety viewpoints requiring critical consideration, recognize the qualities and shortcomings } \\
\text { of their safety culture, help care giving units distinguish their current patient safety hitches, and benchmark } \\
\text { their scores with different healthcare settings. }\end{array}$ \\
\hline Chapter 19 & $\begin{array}{l}\text { Pharmaco-Economics } \\
\text { Cost-benefit analysis and other pharmacoeconomic tools are ways to analyze the value of the service to } \\
\text { the public. These methods supplement the traditional marketplace value as measured by the prices that the } \\
\text { patient or patron is willing to pay. As third parties continue to pay for a higher percentage of prescriptions } \\
\text { dispensed, pharmacy managers are very cognizant that pharmacy services require continual cost- } \\
\text { justification to survive and thrive in the future. The continuing impact of cost-containment is causing } \\
\text { administrators and policymakers in all health fields to examine closely the costs and benefits of both } \\
\text { proposed and existing programs. It is increasingly evident that private employers and public agencies are } \\
\text { demanding that health programs be evaluated in terms of clinical and social outcomes related to costs } \\
\text { incurred. }\end{array}$ \\
\hline Chapter 20 & $\begin{array}{l}\text { Long Term Care } \\
\text { Pharmacist involvement in long-term care activities grew as a result of these regulations, which include } \\
\text { oversight of provision of medications to nursing facilities and consultant pharmacist duties. Pharmacists } \\
\text { practicing in the field of geriatrics must not only be cognizant of these guidelines, but must also be able to } \\
\text { manage patients with multiple disease states taking multiple medications. Policies and procedures for } \\
\text { organizational aspects, medication orders, ordering and receiving medications from the pharmacy, } \\
\text { medication storage in the nursing facility, disposal of medications, medication administration, and } \\
\text { medication monitoring are required in long-term care facilities. }\end{array}$ \\
\hline Chapter 21. & $\begin{array}{l}\text { Community Liaison Pharmacists in Home Care } \\
\text { The provision of home care has existed since the turn of the last century, when societal concerns regarding } \\
\text { immigration, industrialization, and infectious diseases spawned the need for visiting nurses. Early } \\
\text { homecare services primarily consisted of midwife and nursing assistance for births, and the care of } \\
\text { influenza and tuberculosis patients. This early form of home care paved the way for the development of } \\
\text { alternate site healthcare. In the past, the term home care generally referred to community-based nursing } \\
\text { services provided to patients in their homes. Today, the term has been expanded to include home/alternate } \\
\text { site healthcare and encompasses: long-term care, and skilled nursing facilities, assisted living and subacute } \\
\text { facilities, home care, diagnostic centers, outpatient clinics, ambulatory surgery, rehabilitation facilities, } \\
\text { and emergency service markets. }\end{array}$ \\
\hline Chapter 22. & Pharmacists in Ambulatory Care \\
\hline & $\begin{array}{l}\text { Pharmacy is evolving from a product-oriented to a patient-oriented profession. This role modification is } \\
\text { extremely healthy for the patient, the pharmacist, and other members of the health-care team. However, } \\
\text { the evolution will present pharmacists with a number of new challenges. Now, more than in the past, } \\
\text { pharmacists must make the acquisition of contemporary practice knowledge and skills a high priority, to } \\
\text { render the level of service embodied in the concept of pharmaceutical care. Pharmacy educators' } \\
\text { organizations and regulatory bodies must all work together to support pharmacists as they assume } \\
\text { expanded health-care roles. Pharmacy and the health-care industry must work to ensure that the pharmacist } \\
\text { is compensated justly for all services. But before this can happen it will be necessary for pharmacy to } \\
\text { demonstrate value-added to the cost of the prescription. Marketing of the purpose of pharmacy in the } \\
\text { health-care morass and of the services provided by the pharmacist is needed to generate an appropriate }\end{array}$ \\
\hline
\end{tabular}




\begin{tabular}{|c|c|}
\hline & $\begin{array}{l}\text { perceived value among purchasers and users of health-care services. Pharmacists should view themselves } \\
\text { as dispensers of therapy and drug effect interpretations as well as of drugs themselves. Service components } \\
\text { of pharmacy should be identified clearly to third party payers and be visible to consumers, so that they } \\
\text { know what is available at what cost and how it may be accessed. In the future, pharmacy services must be } \\
\text { evaluated on patient outcome (i.e., pharmaceutical care) rather than the number of prescriptions dispensed, } \\
\text { and pharmacy must evolve toward interpretation and patient consultation, related to the use of medication } \\
\text { technologies. }\end{array}$ \\
\hline Chapter 23. & $\begin{array}{l}\text { Pharmacists in ICU } \\
\text { Clinical pharmacists make an essential contribution to the safe and effective use of medicines in critically } \\
\text { ill patients. Few niche clinical pharmacy areas have documented the powerful impact a pharmacist's } \\
\text { presence can have in the way it has been done in critical care. Direct patient care via pharmacist medication } \\
\text { review is an important resource for reducing medication errors and optimizing medication use. } \\
\text { Recommendations for changes to medication therapy related to these medication reviews have very high } \\
\text { acceptance rates by critical care medical teams. Pharmacist prescribing to action the outcomes of their own } \\
\text { medication reviews would be anticipated to reduce the workload of medical colleagues and improve } \\
\text { efficiency. Moreover, pharmacist instigation of medication therapy planned by the multidisciplinary team } \\
\text { may also offer advantages with respect to getting treatment right the first time in specific areas, for } \\
\text { example, therapeutic drug monitoring or drug dosing in multiorgan failure. }\end{array}$ \\
\hline Chapter 24. & $\begin{array}{l}\text { Rational Use of Drugs } \\
\text { Many medicines now exist that can prevent, alleviate, treat, or cure diseases which previously took } \\
\text { inordinate tolls on the health and well-being of children, families, communities, and populations. However, } \\
\text { the overuse, underuse, or misuse of medicines (also referred to as irrational medicine use) puts these } \\
\text { advances in jeopardy and, in addition to wasting limited resources, threatens future public health gains. } \\
\text { The challenge of irrational medicine use is a global one-common to all countries and all healthcare } \\
\text { settings. Both healthcare providers and patients contribute to irrational medicine use. Providers may } \\
\text { prescribe too many, too few, or inappropriate medicines; or may prescribe the appropriate medicines in the } \\
\text { wrong dose, formulation, or duration. Additionally, patients contribute to irrational medicine use through } \\
\text { self-medication, pill sharing, or not completing a treatment regimen as prescribed. }\end{array}$ \\
\hline \multirow[t]{2}{*}{ Chapter 25.} & $\begin{array}{l}\text { Surgical Wound Enrichments } \\
\text { Wound healing is a highly complex process that results in the restoration of cell structures and tissue layers } \\
\text { after an injury. It involves interdependent and overlapping }\end{array}$ \\
\hline & $\begin{array}{l}\text { cellular, physiological, biochemical, and molecular processes. There are numerous wound dressings and } \\
\text { management techniques available today. The challenge lies not only in choosing the correct dressing, but } \\
\text { also in using the chosen technique properly. This involves careful assessment of the wound, taking into } \\
\text { account its size, the exudate, and the patient's preferences. Health care professionals require basic } \\
\text { knowledge of dressings for correct application, and the wound should be monitored closely to ensure } \\
\text { effective healing. Pharmacists can encourage improvement in wound care for patients who have recently } \\
\text { undergone surgery by helping them select the appropriate postsurgical wound care products and by } \\
\text { educating them on proper wound care. }\end{array}$ \\
\hline Chapter 26. & $\begin{array}{l}\text { Medication Risk Management } \\
\text { Medications are the most common treatment intervention used in healthcare around the world. Medication } \\
\text { is given to almost every patient in hospital and can be the most important part of treatment. When used } \\
\text { safely and appropriately, they contribute to significant improvements in the health and well-being of } \\
\text { patients. However, medication is not without risk and occasionally medications can cause harm. } \\
\text { Medication safety issues can impact health outcomes, length of stay in a healthcare facility, readmission } \\
\text { rates, and overall costs to the healthcare system. Some harm caused by medicines is due to errors that are } \\
\text { preventable. The US FDA approve drugs only if they are determined to be safe to use for the conditions } \\
\text { described in their label. This basic tenet of the Food, Drug and Cosmetic Act has not changed. What has } \\
\text { changed though in recent years is the interpretation of the term "safe." Modern concepts of pharmaceutical } \\
\text { risk management are based on the premise that drug manufacturers, health care professionals, and patients } \\
\text { have a responsibility to minimize the risks of using pharmaceutical products. Hospitals and health services } \\
\text { aim to prevent harm by: understanding what contributes to these errors, taking action, sharing this } \\
\text { information with the community and health professionals. It is not enough to make drugs minimally safe; } \\
\text { they must be as safe as possible over the lifecycle of the product's use. However, starting in the early } \\
\text { 1990s, FDA began to take a more active role in post-marketing surveillance and began instituting a more } \\
\text { aggressive "management" process to assure greater safety in the use of marketed drugs. No longer do the } \\
\text { manufacturer and FDA provide passive oversight and labeling changes to control risks, now the } \\
\text { manufacturer must actively monitor for suspected, but unquantified risks and actively manage and } \\
\text { minimize known risks. }\end{array}$ \\
\hline
\end{tabular}




\begin{tabular}{|c|c|}
\hline Chapter 27. & $\begin{array}{l}\text { Medication History Taking and Reconciliation } \\
\text { Patients are at risk of DRPs at transition points during hospitalization. The community pharmacist is often } \\
\text { the first healthcare professional patients visit after discharge. Medication reconciliation, the process of } \\
\text { identifying the most accurate list of all patient's medications is a strategy to identify many medication } \\
\text { discrepancies and reduce potential harm. Medication reconciliation at transitions of care decreases } \\
\text { medication errors, hospitalizations, and adverse drug events. Obtaining medication histories and } \\
\text { conducting medication reconciliation are challenging tasks for the health professionals. Part of ADEs is } \\
\text { due to medication discrepancies, or unexplained variations in medications in hospital admission and } \\
\text { discharge or across different sites of care. Significant number of all hospital prescribing errors originate } \\
\text { from incorrect admission medication histories, the DRPs are only discovered through patient interview, } \\
\text { and more than half of discharge discrepancies are associated with admission discrepancies. ADEs } \\
\text { associated with medication discrepancies can prolong hospital stays and, in the post-discharge period, may } \\
\text { lead to emergency room visits, hospital readmissions, and utilization of other healthcare resources } \\
\text { Pharmacists have proven themselves in both histories recording and reconciliation. True }\end{array}$ \\
\hline & $\begin{array}{l}\text { collaboration with allied health professions enhance this process. A reconciliation of medications } \\
\text { supported by efficient communication between the hospital staff and community pharmacists, in addition } \\
\text { to a standard patient interview and a general practitioner's examination of prescriptions, was found to be } \\
\text { effective in identifying medication discrepancies for patients }\end{array}$ \\
\hline Chapter 28. & $\begin{array}{l}\text { Palliative and Hospice Care } \\
\text { One of the main goals of medicine is to provide comfort and relief from pain and suffering. Unfortunately, } \\
\text { a cure is not always possible particularly in this era of chronic diseases, and the role of physicians has } \\
\text { become limited to controlling and palliating symptoms. Palliative care is a relatively new specialty that } \\
\text { evolved during the last five decades. The aim of this specialty was to provide end of life care for patients } \\
\text { with advanced cancer and their families. In addition, pastoral care is also included according to the religious } \\
\text { beliefs of the patient. The other important components of palliative care are effective communication and } \\
\text { planning and coordination of care. It is noteworthy that ensuring the availability of palliative care services } \\
\text { is an obligation of health care systems under international human rights law. Hospice care is a type of } \\
\text { palliative care with a few differences. Pharmacists in care team can play a major role in different care } \\
\text { settings. }\end{array}$ \\
\hline Chapter 29. & $\begin{array}{l}\text { Non-Drug Pain Management } \\
\text { The vast majority are eager to do pretty much anything to get away from the grasps of interminable agony. } \\
\text { One of the primary cures offered to endless torment sufferers is prescription medications. Prescription } \\
\text { painkillers are compelling much of the time. Be that as it may, the relief from discomfort they offer includes } \\
\text { some major disadvantages for some. Painkillers risk getting to be addictive. What's more, as endless news } \\
\text { reports have appeared, the consequences of dependence on painkillers can be wrecking. Non-tranquilize } \\
\text { therapies decline torment and can be utilized notwithstanding pharmaceuticals or in lieu of } \\
\text { pharmaceuticals. They offer the likelihood to enhance your personal satisfaction. Similarly, as with some } \\
\text { other treatment, every individual will react distinctively to various therapies, and there is no certification } \\
\text { that any treatment will give total help with discomfort. Though many evidences were weaker, the } \\
\text { researchers also found that massage therapy, spinal manipulation, and osteopathic manipulation may } \\
\text { provide some help for back pain, fibromyalgia, osteoarthritis, cancer pain, knee replacement, migraine, } \\
\text { frozen shoulder and chronic non-migraine headache. These data can equip providers and patients with the } \\
\text { information they need to have informed conversations regarding non-drug approaches for treatment of } \\
\text { specific pain conditions. It's important that continued research explore how these approaches actually work } \\
\text { and whether these findings apply broadly in diverse clinical settings and patient populations. }\end{array}$ \\
\hline
\end{tabular}

Table 1. Book Compendium

\section{Key Features of the book}

$\rightarrow$ The book solely focuses on job responsibilities of patient care pharmacists, separated from those of doctors and nurses, with the most recent information.

$\rightarrow$ Various aspects of pharmacist-led patient care services are incorporated in a single book.

$\rightarrow$ Career-focused discussions in every chapter with structured guidelines provided for the pharmacists.

$\rightarrow$ Content is mostly based on recent pharmacists' activities in the healthcare arena of developed countries.

$\rightarrow$ Chapter outline, abbreviations, synopsis, learning outcomes, cases, key terms and further references are added like a textbook. $\rightarrow$ Possible errors during the patient dealing and measures to be taken in all aspects are thoroughly discussed.

$\rightarrow$ The future prospect of patient care pharmacists in different areas of health care elaborately discussed.

$\rightarrow$ Discusses patient relationship management with a caring and compassionate touch which is a very demanding approach to many high-profile healthcare settings.

$\rightarrow$ Along with professionals, undergraduate students can utilize this book as a reference for their courses like hospital and community pharmacy and pharmaceutics.

$\rightarrow$ Scholars from countries around the world are giving their recommendation about the book. 


\begin{tabular}{|c|c|c|c|c|c|}
\hline Author & Title & Publisher & Price & Details & $\begin{array}{l}\text { Superiority of Proposed } \\
\text { Title }\end{array}$ \\
\hline $\begin{array}{l}\text { Richard } \\
\text { Finkel }\end{array}$ & $\begin{array}{l}\text { Patient Care } \\
\text { Management } \\
\text { Lab: A } \\
\text { Workbook for } \\
\text { Prescription Practice }\end{array}$ & $\begin{array}{l}\text { Lippincott } \\
\text { Williams \& } \\
\text { Wilkins, Feb } \\
\text { 1, } 2007\end{array}$ & $\begin{array}{l}\text { Kindle } \\
\text { Edition } \\
74 \text { USD } \\
\text { Spiral } \\
\text { Bound: } \\
47 \text { USD }\end{array}$ & $\begin{array}{l}\text { Develops and fine tunes } \\
\text { pharmacy and pharmacy } \\
\text { technician students' skills } \\
\text { in reading, evaluating, and } \\
\text { filling prescriptions. }\end{array}$ & $\begin{array}{l}\text { Other than prescription } \\
\text { handling, patient care } \\
\text { pharmacists have many other } \\
\text { responsibilities that are } \\
\text { included. }\end{array}$ \\
\hline $\begin{array}{l}\text { Bernard J. } \\
\text { Healey, Marc } \\
\text { C. } \\
\text { Marchese }\end{array}$ & $\begin{array}{l}\text { Foundations of } \\
\text { Health Care } \\
\text { Management: } \\
\text { Principles and } \\
\text { Methods }\end{array}$ & $\begin{array}{l}\text { John Wiley \& } \\
\text { Sons, Aug 9, } \\
2012\end{array}$ & $\begin{array}{l}\text { E-book } \\
72.99 \\
\text { USD } \\
\text { Paperback } \\
90 \text { USD }\end{array}$ & $\begin{array}{l}\text { The book covers such } \\
\text { critical topics as } \\
\text { leadership training, } \\
\text { change management, } \\
\text { conflict management } \\
\text { techniques, culture } \\
\text { building, quality } \\
\text { improvement, and } \\
\text { communications skills, as } \\
\text { well as collaboration in } \\
\text { the improvement of } \\
\text { population health. }\end{array}$ & $\begin{array}{l}\text { Patient care pharmacists } \\
\text { need more coverage in areas } \\
\text { of counseling, patient } \\
\text { education, relationship } \\
\text { management, understanding } \\
\text { patient behavior, safety } \\
\text { concerns, ethical issues and } \\
\text { framework for safety in } \\
\text { several stages of drug } \\
\text { handling etc. are covered. }\end{array}$ \\
\hline $\begin{array}{l}\text { Seth B. } \\
\text { Goldsmith }\end{array}$ & $\begin{array}{l}\text { Principles of } \\
\text { Health Care } \\
\text { Management: } \\
\text { Foundations for a } \\
\text { Changing Health } \\
\text { Care System }\end{array}$ & $\begin{array}{l}\text { Jones \& } \\
\text { Bartlett } \\
\text { Publishers, Oct } \\
25,2010\end{array}$ & $\begin{array}{l}\text { Paperback } \\
192.95 \\
\text { USD }\end{array}$ & $\begin{array}{l}\text { Hospital administration- } \\
\text { based book, using relevant } \\
\text { case studies to illustrate } \\
\text { key points, this text } \\
\text { explains the critical } \\
\text { changes and challenges } \\
\text { that administrators must } \\
\text { deal }\end{array}$ & $\begin{array}{l}\text { Pharmacists' role at every } \\
\text { stages of patient handling is } \\
\text { clearly defined along with the } \\
\text { superiority of their services } \\
\text { among other professionals in } \\
\text { the healthcare arena. }\end{array}$ \\
\hline $\begin{array}{l}\text { Michael } \\
\text { D. Hogue }\end{array}$ & $\begin{array}{l}\text { The } \\
\text { Pharmacist's } \\
\text { Guide to } \\
\text { Compensation } \\
\text { for Patient-care } \\
\text { Services }\end{array}$ & $\begin{array}{l}\text { American } \\
\text { Pharmaceutical } \\
\text { Association, } \\
2002\end{array}$ & $\begin{array}{l}\text { Paperback } \\
249.01 \\
\text { USD }\end{array}$ & $\begin{array}{l}\text { This comprehensive book } \\
\text { covers all aspects of } \\
\text { compensation for } \\
\text { medication therapy } \\
\text { management services } \\
\text { provided by pharmacists } \\
\text { in all practice settings }\end{array}$ & $\begin{array}{l}\text { Other than pharmacists' } \\
\text { compensation issues, } \\
\text { every aspect pharmacy in } \\
\text { patient care discussed } \\
\text { deliberately as } \\
\text { compensation of the } \\
\text { professionals are not part } \\
\text { of patient care. }\end{array}$ \\
\hline $\begin{array}{l}\text { Gwen } \\
\text { Marram } \\
\text { Van } \\
\text { Servellen }\end{array}$ & $\begin{array}{l}\text { Communication } \\
\text { Skills for the } \\
\text { Health Care } \\
\text { Professional: } \\
\text { Concepts, } \\
\text { Practice, and } \\
\text { Evidence }\end{array}$ & $\begin{array}{l}\text { Jones \& } \\
\text { Bartlett } \\
\text { Publishers, Oct } \\
7,2009\end{array}$ & $\begin{array}{l}\text { Paperback } \\
\$ 92.06 \\
\text { Kindle } \\
\text { Edition } \\
\$ 3.49\end{array}$ & $\begin{array}{l}\text { It provides future and } \\
\text { practicing patient } \\
\text { caregivers in all } \\
\text { specialties and services } \\
\text { with basic communication } \\
\text { knowledge and skills and } \\
\text { is an invaluable resource } \\
\text { for those in administrative } \\
\text { functions as well. }\end{array}$ & $\begin{array}{l}\text { Along with communication, } \\
\text { patient care pharmacists have } \\
\text { to cover safety concerns, } \\
\text { vigilance, drug and healthcare } \\
\text { costing calculation, medicine } \\
\text { reconciliation issues that are } \\
\text { discussed giving similar } \\
\text { priority. }\end{array}$ \\
\hline $\begin{array}{l}\text { Colleen } \\
\text { Doherty } \\
\text { Lauster, } \\
\text { Sneha } \\
\text { Baxi } \\
\text { Srivastava }\end{array}$ & $\begin{array}{l}\text { Fundamental } \\
\text { Skills for } \\
\text { Patient Care in } \\
\text { Pharmacy } \\
\text { Practice }\end{array}$ & $\begin{array}{l}\text { Jones \& } \\
\text { Bartlett } \\
\text { Publishers, } \\
2013\end{array}$ & $\begin{array}{l}104.95 \\
\text { USD }\end{array}$ & $\begin{array}{l}\text { Drug related problems and } \\
\text { counseling well discussed. }\end{array}$ & $\begin{array}{l}\text { Along with drug related } \\
\text { problems, patient problems, } \\
\text { safety concerns, home care } \\
\text { and long-term care are also } \\
\text { discussed. }\end{array}$ \\
\hline
\end{tabular}




\begin{tabular}{|c|c|c|c|c|c|}
\hline $\begin{array}{l}\text { American } \\
\text { Pharmacists } \\
\text { Association }\end{array}$ & $\begin{array}{l}\text { How to Implement } \\
\text { the Pharmacists' } \\
\text { Patient Care Process }\end{array}$ & $\begin{array}{l}\text { American } \\
\text { Pharmacists } \\
\text { Association, } 2015\end{array}$ & 78.07 USD, & $\begin{array}{l}\text { Policy related book, aims } \\
\text { to help pharmacists } \\
\text { understand the } \\
\text { components of the patient } \\
\text { care process and apply the } \\
\text { process to patients in all } \\
\text { pharmacy practice } \\
\text { settings. Six sample case } \\
\text { studies set in different } \\
\text { patient care settings } \\
\text { enable the reader to } \\
\text { practice applying the } \\
\text { patient care process. }\end{array}$ & $\begin{array}{l}\text { Patient care process discussed } \\
\text { through issues like } \\
\text { counseling, compliance, } \\
\text { framework of safety, patient } \\
\text { safety concern, cost saving } \\
\text { and vigilance. }\end{array}$ \\
\hline $\begin{array}{l}\text { Thomas R. } \\
\text { Brown }\end{array}$ & $\begin{array}{l}\text { Handbook of } \\
\text { Institutional } \\
\text { Pharmacy Practice }\end{array}$ & $\begin{array}{l}\text { American Society } \\
\text { of Hospital } \\
\text { Pharmacists, } 2006\end{array}$ & 31.89 USD & $\begin{array}{l}\text { An overview of health } \\
\text { delivery systems and } \\
\text { hospital pharmacy through } \\
\text { various practice settings } \\
\text { such as home care, long } \\
\text { term care, hospice and } \\
\text { palliative care, ambulatory } \\
\text { care, and managed care } \\
\text { this text focuses on } \\
\text { various elements } \\
\text { important to health-system } \\
\text { pharmacies. The } \\
\text { Handbook of Institutional } \\
\text { Pharmacy Practice is the } \\
\text { first step in developing a } \\
\text { career in pharmacy and } \\
\text { provides opportunities for } \\
\text { study in career } \\
\text { enhancement. }\end{array}$ & $\begin{array}{l}\text { Many concepts of the } \\
\text { proposed book resemble to } \\
\text { Handbook of Institutional } \\
\text { Pharmacy Practice but } \\
\text { content is different. } \\
\text { Moreover, studies discussed } \\
\text { in proposed book are at least } \\
\text { an era of advanced. }\end{array}$ \\
\hline $\begin{array}{l}\text { Kimberly S. } \\
\text { Plake, } \\
\text { Kenneth W. } \\
\text { Schafermeyer, } \\
\text { Robert L. } \\
\text { McCarthy }\end{array}$ & $\begin{array}{l}\text { McCarthy's } \\
\text { Introduction to } \\
\text { Health Care } \\
\text { Delivery: A Primer } \\
\text { for Pharmacists }\end{array}$ & $\begin{array}{l}\text { Jones \& Bartlett } \\
\text { Publishers, } 2016\end{array}$ & 46.93 USD & $\begin{array}{l}\text { A Primer for Pharmacists, } \\
\text { Sixth Edition provides } \\
\text { students with a current and } \\
\text { comprehensive overview } \\
\text { of the U.S. health care } \\
\text { delivery system, including } \\
\text { social, organizational, and } \\
\text { economic aspects, from the } \\
\text { perspective of the } \\
\text { pharmacy profession. }\end{array}$ & $\begin{array}{l}\text { The book is far better than the } \\
\text { proposed book but the book } \\
\text { focuses on overall } \\
\text { pharmacists' roles toward } \\
\text { profession. The proposed } \\
\text { book only focuses roles of } \\
\text { patient care pharmacists and } \\
\text { the content is different from } \\
\text { McCarthy. }\end{array}$ \\
\hline
\end{tabular}

Table 2. Comparison with Similar Available Books

\section{Author Profile}

Author (Figure 2) completed B.Pharm (2004) and M.Pharm (2006) from Department of Pharmaceutical Technology, Faculty of Pharmacy, University of Dhaka. He has completed his MBA (2007) from East West University. He was in faculty of Pharmacy, World University of Bangladesh as an Assistant Professor. Along with 8 years of teaching experience, he also worked for reputed pharmaceutical companies in strategic management for 5 years. He authored 11 books (Table 3) and many articles on alternative medicines, patient care, marine drug sources and other recent issues of healthcare in several journals (Table 4) and newspapers (Table 5). He is now acting secretary and treasurer in Dr. M. Nasirullah Memorial Trust.

\begin{tabular}{|c|l|l|l|l|}
\hline No. & Book & Publisher & $\begin{array}{l}\text { Year } \\
\text { Published }\end{array}$ & Role \\
\hline 1. & The Role of the Pharmacist in Patient Care & $\begin{array}{l}\text { Universal-Publishers (US). (ISBN- } \\
10: 1627343083 \\
\text { ISBN-13: 9781627343084) }\end{array}$ & $\begin{array}{l}\text { So20 } \\
\text { Author }\end{array}$ \\
\hline $\mathbf{2 .}$ & $\begin{array}{l}\text { A Comprehensive Chemical and } \\
\text { Pharmacological Review of Cosmetics }\end{array}$ & $\begin{array}{l}\text { Nova Science Publishing Inc. (US), } \\
\text { ISBN: 978-1-53618-571-3 }\end{array}$ & 2020 & $\begin{array}{l}\text { Sole } \\
\text { Author }\end{array}$ \\
\hline 3. & A Review of Pharmaceutical Science & $\begin{array}{l}\text { GRIN Verlag, 2020 (Munich, } \\
\text { Germany) (ISBN 3346214184, } \\
\text { 9783346214188) }\end{array}$ & 2020 & $\begin{array}{l}\text { Sole } \\
\text { Author }\end{array}$ \\
\hline
\end{tabular}




\begin{tabular}{|c|c|c|c|c|}
\hline 4. & $\begin{array}{l}\text { Nature and Nutrition: A New Era of } \\
\text { Therapeutic Herbs }\end{array}$ & $\begin{array}{l}\text { Nova Science Publishing Inc. (US), } \\
\text { (ISBN 9781536158922) }\end{array}$ & 2019 & $\begin{array}{l}\text { Sole } \\
\text { Author }\end{array}$ \\
\hline 5. & $\begin{array}{l}\text { Non-drug pain management: opportunities } \\
\text { to explore (e-Book) }\end{array}$ & $\begin{array}{l}\text { BiomedGrid LLC, USA May 09, } \\
2019 \text { (ISBN: 978-1-946628-01-5) }\end{array}$ & 2019 & $\begin{array}{l}\text { Sole } \\
\text { Author }\end{array}$ \\
\hline 6. & $\begin{array}{l}\text { Common GI Disorders \& Alternative } \\
\text { Measures (e-Book) }\end{array}$ & $\begin{array}{l}\text { LAP LAMBERT Academic } \\
\text { Publishing (ISBN-13: 978-613-9- } \\
\text { 47148-5) }\end{array}$ & 2019 & $\begin{array}{l}\text { Sole } \\
\text { Author }\end{array}$ \\
\hline 7. & $\begin{array}{l}\text { A Comprehensive Review of Surgical } \\
\text { Supplies (e-Book) }\end{array}$ & $\begin{array}{l}\text { Peernest, US August 13, } 2019 \\
\text { (ISBN: 978-1-946628-24-4) }\end{array}$ & 2019 & $\begin{array}{l}\text { Sole } \\
\text { Author }\end{array}$ \\
\hline 8. & $\begin{array}{l}\text { Skin Aging and Modern Age Antiaging } \\
\text { Strategies (e-Book) }\end{array}$ & $\begin{array}{l}\text { Peernest, US July 23, } 2019 \text { (ISBN: } \\
\text { 978-1-946628-23-7) }\end{array}$ & 2019 & $\begin{array}{l}\text { Sole } \\
\text { Author }\end{array}$ \\
\hline 9. & $\begin{array}{l}\text { A Pharmacological Review of Sunscreens } \\
\text { and Suntan Preparations (e-Book) }\end{array}$ & $\begin{array}{l}\text { Peertechz Publications, India August } \\
\text { 05, } 2019 \text { (ISBN: 978-81-943057-1- } \\
\text { 2, DOI: } 10.17352 / \text { ebook10112) }\end{array}$ & 2019 & $\begin{array}{l}\text { Sole } \\
\text { Author }\end{array}$ \\
\hline 10. & Medicinal Values of Seaweeds (e-Book) & $\begin{array}{l}\text { Academic Publications, India } \\
\text { (ISBN: 978-81-943354-4-3) }\end{array}$ & 2019 & $\begin{array}{l}\text { Sole } \\
\text { Author }\end{array}$ \\
\hline 11. & $\begin{array}{l}\text { Clinical Pharmacists in Chronic Care } \\
\text { Management (e-Book) }\end{array}$ & $\begin{array}{l}\text { Academic Publications, India } \\
\text { (ISBN: 978-81-943354-0-5) }\end{array}$ & 2019 & $\begin{array}{l}\text { Sole } \\
\text { Author }\end{array}$ \\
\hline
\end{tabular}

Table 3. Author's Published Books

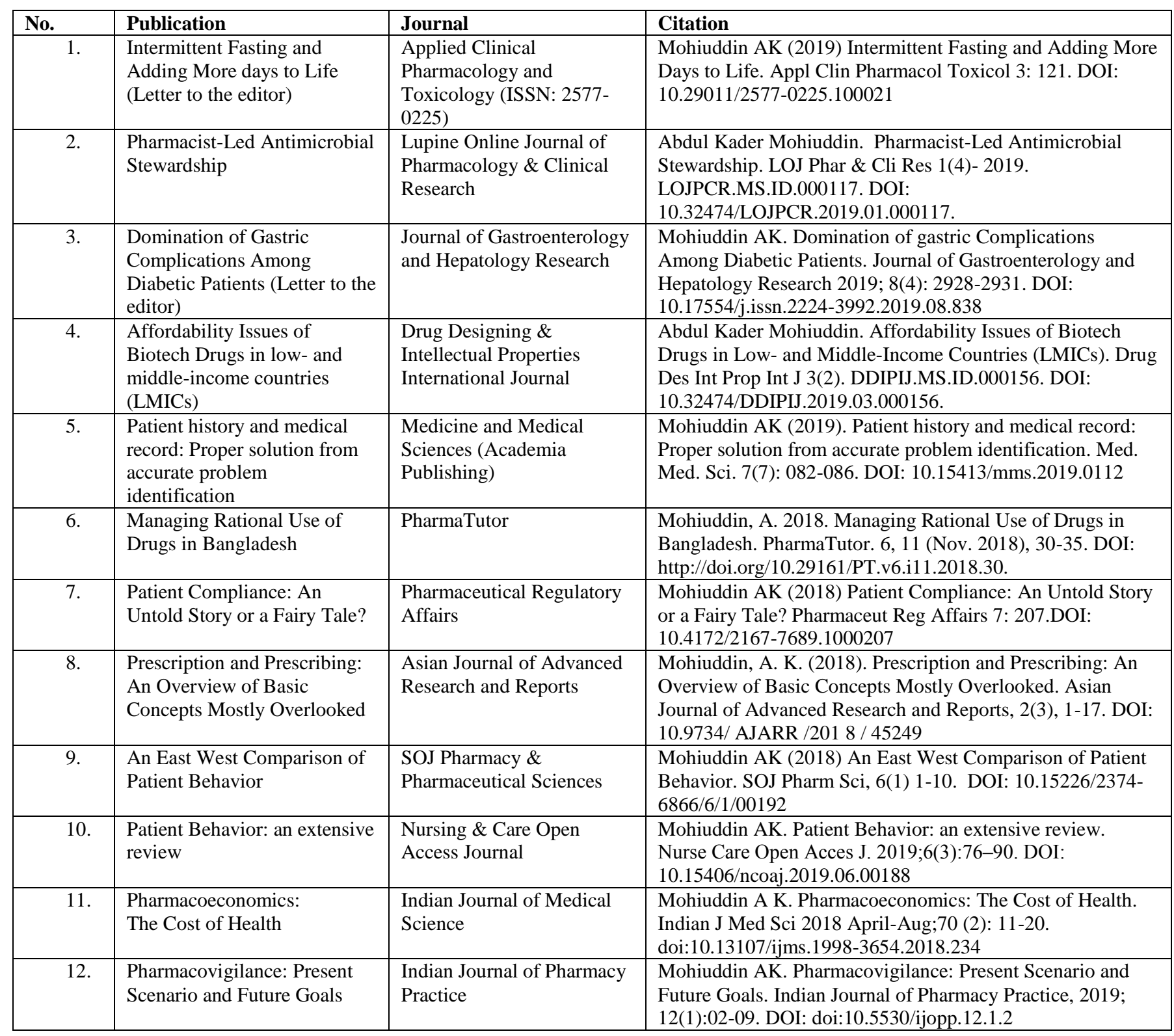




\begin{tabular}{|c|c|c|c|}
\hline 13. & $\begin{array}{l}\text { Patient-Provider Relationship: } \\
\text { Compliance with Care }\end{array}$ & $\begin{array}{l}\text { Research Journal of } \\
\text { Medical Sciences }\end{array}$ & $\begin{array}{l}\text { A.K. Mohiuddin, 2019. Patient-Provider Relationship: } \\
\text { Compliance with Care. Research Journal of Medical } \\
\text { Sciences, 13: 25-37. DOI: 10.3923/rjmsci.2019.25.37 }\end{array}$ \\
\hline 14. & $\begin{array}{l}\text { Pharmacists in Public Health: } \\
\text { Scope in Home and Abroad }\end{array}$ & $\begin{array}{l}\text { SOJ Pharmacy \& } \\
\text { Pharmaceutical Sciences }\end{array}$ & $\begin{array}{l}\text { Mohiuddin AK (2019) Pharmacists in Public Health: Scope } \\
\text { in Home and Abroad. SOJ Pharm Sci 6(1):1-23. DOI: } \\
10.15226 / 2374-6866 / 6 / 1 / 00196\end{array}$ \\
\hline 15. & $\begin{array}{l}\text { Ethics and Professionalism: } \\
\text { Pharmacy Profession }\end{array}$ & $\begin{array}{l}\text { American Journal of Public } \\
\text { administration }\end{array}$ & $\begin{array}{l}\text { AK Mohiuddin. Ethics and Professionalism: Pharmacy } \\
\text { Profession. American Journal of Public administration, } \\
\text { 2019,1:3. DOI:10.28933/AJPA }\end{array}$ \\
\hline 16. & $\begin{array}{l}\text { Patient Rights in Pharmacy } \\
\text { Profession }\end{array}$ & $\begin{array}{l}\text { American Journal of Public } \\
\text { administration }\end{array}$ & $\begin{array}{l}\text { AK Mohiuddin. Patient Rights in Pharmacy Profession. } \\
\text { American Journal of Public administration, 2019,1:5. } \\
\text { DOI:10.28933/AJPA }\end{array}$ \\
\hline 17. & $\begin{array}{l}\text { Patient Education: Steps } \\
\text { Towards Compliance }\end{array}$ & $\begin{array}{l}\text { Journal of Pharmacology \& } \\
\text { Clinical Research }\end{array}$ & $\begin{array}{l}\text { Mohiuddin AK. Patient Education: Steps Towards } \\
\text { Compliance. J of Pharmacol \& Clin Res. 2019; 6(5): } 555700 . \\
\text { DOI: 10.19080/JPCR.2019.06.555700 }\end{array}$ \\
\hline 18. & $\begin{array}{l}\text { Pharmaco-economics: } \\
\text { Essential but merely practiced } \\
\text { in Bangladesh }\end{array}$ & $\begin{array}{l}\text { Academia Journal of } \\
\text { Scientific Research }\end{array}$ & $\begin{array}{l}\text { Mohiuddin AK (2018). Pharmaco-economics: Essential but } \\
\text { merely practiced in Bangladesh. Acad. J. Sci. Res. 7(3): 182- } \\
\text { 187. DOI: } 10.15413 / \text { ajsr.2018.0195 }\end{array}$ \\
\hline 19. & $\begin{array}{l}\text { Risks and Reasons Associated } \\
\text { with Medication Non- } \\
\text { Adherence }\end{array}$ & $\begin{array}{l}\text { Journal of Clinical } \\
\text { Pharmacy }\end{array}$ & $\begin{array}{l}\text { Mohiuddin AK (2019) Risks and Reasons Associated with } \\
\text { Medication Non-Adherence. J Clin Pharm Vol: 1, Issu: } 1 \\
\text { (50-53). DOI: 10.3619/JCP.1000105 }\end{array}$ \\
\hline 20. & $\begin{array}{l}\text { Patient History \& Medical } \\
\text { Record: Proper Solution from } \\
\text { Accurate Problem } \\
\text { Identification (Letter to the } \\
\text { editor) }\end{array}$ & $\begin{array}{l}\text { International Journal of } \\
\text { Current Science and } \\
\text { Multidisciplinary Research }\end{array}$ & $\begin{array}{l}\text { Mohiuddin AK. Patient History \& Medical Record: Proper } \\
\text { Solution from Accurate Problem Identification. International } \\
\text { Journal of Current Science and Multidisciplinary Research } \\
\text { Volume 2, Issue 07, Page 115-120. }\end{array}$ \\
\hline 21. & $\begin{array}{l}\text { Clinical Pharmacists in } \\
\text { Pediatric Units }\end{array}$ & $\begin{array}{l}\text { Acta Scientific } \\
\text { Pharmaceutical Sciences } \\
\text { (ISSN: 2581-5423) }\end{array}$ & $\begin{array}{l}\text { Abdul Kader Mohiuddin. "Clinical Pharmacists in Pediatric } \\
\text { Units". Acta Scientific Pharmaceutical Sciences } 3.8 \text { (2019): } \\
\text { 41-44. }\end{array}$ \\
\hline 22. & $\begin{array}{l}\text { Pharmacists in Aged Care } \\
\text { Facilities }\end{array}$ & $\begin{array}{l}\text { International Journal of } \\
\text { Aging Research }\end{array}$ & $\begin{array}{l}\text { Abdul Kader Mohiuddin. Pharmacists in Aged Care } \\
\text { Facilities. International Journal of Aging Research, 2019, } \\
2: 41\end{array}$ \\
\hline 23. & $\begin{array}{l}\text { A Brief Review of Indigenous } \\
\text { Plants as Sources of } \\
\text { Pharmacological Interests }\end{array}$ & $\begin{array}{l}\text { International Journal of } \\
\text { Traditional and } \\
\text { Complementary Medicine }\end{array}$ & $\begin{array}{l}\text { AK Mohiuddin. A Brief Review of Indigenous Plants as } \\
\text { Sources of Pharmacological Interests. International Journal } \\
\text { of Traditional and Complementary Medicine } 2019,4: 13 \text {. } \\
\text { DOI: } 10.28933 / \text { ijtcm-2019-01-0206 }\end{array}$ \\
\hline 24. & $\begin{array}{l}\text { Characterization of Chemical } \\
\text { Groups and Study of } \\
\text { Antioxidant, Antidiarrhoeal, } \\
\text { Antimicrobial and Cytotoxic } \\
\text { activities of ethanolic extract } \\
\text { of bacopa moneri (Family: } \\
\text { Ebenaceae) Leaves }\end{array}$ & $\begin{array}{l}\text { Journal of Pharmacy } \\
\text { Research }\end{array}$ & $\begin{array}{l}\text { Howlader MSI, Sayeed MSB, Ahmed MU, Mohiuddin AK, } \\
\text { Labu ZK, Bellah SF, Islam MS. Characterization of } \\
\text { Chemical Groups and Study of Antioxidant, Antidiarrhoeal, } \\
\text { Antimicrobial and Cytotoxic activities of ethanolic extract of } \\
\text { bacopa moneri (Family: Ebenaceae) Leaves. Journal of } \\
\text { Pharmacy Research 2012,5(6),3050-3052 }\end{array}$ \\
\hline 25. & $\begin{array}{l}\text { Thrombolytic, Membrane } \\
\text { stabilizing, Antidiarrhoeal, } \\
\text { and Antimicrobial Properties } \\
\text { of Bioactive Compounds } \\
\text { Isolated from leaves of } \\
\text { Sesbania grandiflora } \\
\text { Naturally Growing in } \\
\text { Bangladesh }\end{array}$ & $\begin{array}{l}\text { Iranian Journal of } \\
\text { Pharmaceutical Sciences }\end{array}$ & $\begin{array}{l}\text { binte Arfan N, Islam T, Sultana Julie A, Mohiuddin AK, } \\
\text { Alam Khan S, Khalid Labu Z, Thrombolytic, Membrane } \\
\text { stabilizing, Antidiarrhoeal and Antimicrobial Properties } \\
\text { of Bioactive Compounds Isolated from leaves of Sesbania } \\
\text { grandiflora Naturally Growing in Bangladesh. Iranian } \\
\text { Journal of Pharmaceutical Sciences, 2016, } 12 \text { (3): 31-46 }\end{array}$ \\
\hline 26. & $\begin{array}{l}\text { Medicinal Properties of the } \\
\text { Sesbania grandiflora Leaves }\end{array}$ & $\begin{array}{l}\text { Ibnosina Journal of } \\
\text { Medicine and Biomedical } \\
\text { Sciences }\end{array}$ & $\begin{array}{l}\text { binte Arfan N, Sultana Julie A, Mohiuddin AK, Alam Khan } \\
\text { S, Khalid Labu Z. Ibnosina J Med BS 2016;8(6):271-277. } \\
\text { DOI: 10.4103/1947-489X.210243 }\end{array}$ \\
\hline 27. & $\begin{array}{l}\text { Medicinal and Therapeutic } \\
\text { Values of Sesbania } \\
\text { Grandiflora }\end{array}$ & $\begin{array}{l}\text { International Healthcare } \\
\text { Research Journal }\end{array}$ & $\begin{array}{l}\text { Mohiuddin AK. Medicinal and Therapeutic values of } \\
\text { Sesbania grandiflora. Int Healthc Res J. 2019;3(5):161-166. } \\
\text { https://doi.org/10.26440/IHRJ/0305.08265 }\end{array}$ \\
\hline 28. & $\begin{array}{l}\text { Medical Waste: A Nobody's } \\
\text { Responsibility After Disposal }\end{array}$ & $\begin{array}{l}\text { International Journal of } \\
\text { Environmental Sciences \& } \\
\text { Natural Resources }\end{array}$ & $\begin{array}{l}\text { Ak Mohiuddin. Medical Waste: A Nobody's Responsibility } \\
\text { After Disposal. Int J Environ Sci Nat Res. 2018; 15(2): } \\
\text { 555908. DOI: 10.19080/IJESNR.2018.15.555908. }\end{array}$ \\
\hline 29. & $\begin{array}{l}\text { Extemporaneous } \\
\text { Compounding: Cautions, }\end{array}$ & $\begin{array}{l}\text { Innovative Journal of } \\
\text { Medical and Health Science }\end{array}$ & $\begin{array}{l}\text { Mohiuddin*, A. (2019) "Extemporaneous Compounding: } \\
\text { Cautions, Controversies and Convenience", Innovative }\end{array}$ \\
\hline
\end{tabular}




\begin{tabular}{|c|c|c|c|}
\hline & $\begin{array}{l}\text { Controversies and } \\
\text { Convenience }\end{array}$ & & $\begin{array}{l}\text { Journal of Medical and Health Science, 9(1), pp. 252-264. } \\
\text { doi: } 10.15520 / \text { ijmhs.v9i1.2420. }\end{array}$ \\
\hline 30. & $\begin{array}{l}\text { Domination of Nephrotic } \\
\text { Problems among Diabetic } \\
\text { Patients of Bangladesh }\end{array}$ & $\begin{array}{l}\text { Archives of Pharmacology } \\
\text { and Therapeutics }\end{array}$ & $\begin{array}{l}\text { Mohiuddin AK. Domination of Nephrotic Problems among } \\
\text { Diabetic Patients of Bangladesh. Arch Pharmacol Ther. } \\
\text { 2018; 1(1):8-13. }\end{array}$ \\
\hline 31. & $\begin{array}{l}\text { Risk Associated with } \\
\text { Supplements and Enhancing } \\
\text { Drugs: Letter to the Editor }\end{array}$ & $\begin{array}{l}\text { ARC Journal of Research in } \\
\text { Sports Medicine }\end{array}$ & $\begin{array}{l}\text { AK Mohiuddin, "Risk Associated with Supplements and } \\
\text { Enhancing Drugs: Letter to the Editor" ARC Journal of } \\
\text { Research in Sports Medicine. 2019; 4(1): 9-13. DOI: } \\
\text { 10.13140/RG.2.2.18584.85764 }\end{array}$ \\
\hline 32. & $\begin{array}{l}\text { An A-Z Pharmaceutical } \\
\text { Industry: Bangladesh } \\
\text { Perspective }\end{array}$ & $\begin{array}{l}\text { Asian Journal of Research } \\
\text { in Pharmaceutical Sciences }\end{array}$ & $\begin{array}{l}\text { AK Mohiuddin. An A-Z Pharmaceutical Industry: } \\
\text { Bangladesh Perspective. Asian J. Res. Pharm. Sci. 2019; } \\
\text { 9(1):17-28. DOI No: 10.5958/2231-5659.2019.00004.3 }\end{array}$ \\
\hline 33. & $\begin{array}{l}\text { A Brief Review of Traditional } \\
\text { plants as Sources of } \\
\text { Pharmacological interests }\end{array}$ & $\begin{array}{l}\text { Open Journal of Plant } \\
\text { Science }\end{array}$ & $\begin{array}{l}\text { Mohiuddin AK (2019) A Brief Review of Traditional plants } \\
\text { as Sources of Pharmacological interests. Open J Plant Sci } \\
\text { 4(1): 001-008 DOI: } 10.17352 / \text { ojps.000015 }\end{array}$ \\
\hline 34. & $\begin{array}{l}\text { Chemical Contaminants and } \\
\text { Pollutants in the Measurable } \\
\text { Life of Dhaka City }\end{array}$ & $\begin{array}{l}\text { European Journal of } \\
\text { Sustainable Development } \\
\text { Research }\end{array}$ & $\begin{array}{l}\text { Mohiuddin AK. Chemical Contaminants and Pollutants in } \\
\text { the Measurable Life of Dhaka City. European Journal of } \\
\text { Sustainable Development Research. 2019;3(2), em0083. } \\
\text { https://doi.org/10.29333/ejosdr/5727 }\end{array}$ \\
\hline 35. & $\begin{array}{l}\text { Diabetes Fact: Bangladesh } \\
\text { Perspective }\end{array}$ & $\begin{array}{l}\text { International Journal of } \\
\text { Diabetes Research }\end{array}$ & $\begin{array}{l}\text { Mohiuddin AK. Diabetes Fact: Bangladesh Perspective. Int. } \\
\text { J. Diabetes Res 2019 February; 2(1): 14-20. DOI: } \\
\text { 10.17554/j.issn.2414-2409.2019.02.12 }\end{array}$ \\
\hline 36. & $\begin{array}{l}\text { Natural Foods and Indian } \\
\text { herbs of cardiovascular } \\
\text { interest }\end{array}$ & $\begin{array}{l}\text { Pharmacy \& Pharmacology } \\
\text { International Journal }\end{array}$ & $\begin{array}{l}\text { Mohiuddin AK. Natural Foods and Indian herbs of } \\
\text { cardiovascular interest. Pharm Pharmacol Int J. } \\
\text { 2019;7(2):60 - 84. DOI: } 10.15406 / \text { ppij.2019.07.00235 }\end{array}$ \\
\hline 37. & $\begin{array}{l}\text { Alcohol Induced Fatty Liver: } \\
\text { A Tragic Inception of Wrong } \\
\text { Turn }\end{array}$ & $\begin{array}{l}\text { Jacobs Journal of } \\
\text { Gastroenterology and } \\
\text { Hepatology }\end{array}$ & $\begin{array}{l}\text { Mohiuddin AK. Alcohol Induced Fatty Liver: A Tragic } \\
\text { Inception of Wrong Turn. JJ GASTRO HEPATO 2019; } 6 \\
\text { (1): } 041 .\end{array}$ \\
\hline 38. & $\begin{array}{l}\text { Traditional System of } \\
\text { Medicine and Nutritional } \\
\text { Supplementation: Use Vs } \\
\text { Regulation }\end{array}$ & $\begin{array}{l}\text { Open Journal of } \\
\text { Pharmaceutical Science and } \\
\text { Research }\end{array}$ & $\begin{array}{l}\text { Mohiuddin Ak. 2019. Traditional System of Medicine and } \\
\text { Nutritional Supplementation: Use Vs Regulation. Open J } \\
\text { Pharm Sci Res. 1: 53-98. }\end{array}$ \\
\hline 39. & $\begin{array}{l}\text { A Comprehensive Review of } \\
\text { Acne Vulgaris }\end{array}$ & $\begin{array}{l}\text { Clinical Research in } \\
\text { Dermatology: Open Access }\end{array}$ & $\begin{array}{l}\text { Mohiuddin AK (2019) A Comprehensive Review of Acne } \\
\text { Vulgaris. Clin Res Dermatol Open Access 6(2): 1-3. DOI: } \\
\text { http:// dx.doi.org/10.15226/2378-1726/6/1/00186 }\end{array}$ \\
\hline 40. & $\begin{array}{l}\text { Acne Vulgaris: Pimples No } \\
\text { Not Have Simple Solution }\end{array}$ & $\begin{array}{l}\text { International Journal of } \\
\text { Clinical \& Experimental } \\
\text { Dermatology }\end{array}$ & $\begin{array}{l}\text { Mohiuddin AK. Acne Vulgaris: Pimples No Not Have } \\
\text { Simple Solution. International Journal of Clinical \& } \\
\text { Experimental Dermatology Volume 4, Issue } 1,1 \text { to } 26\end{array}$ \\
\hline 41. & $\begin{array}{l}\text { Skin Aging \& Modern Age } \\
\text { Anti-Aging Strategies }\end{array}$ & $\begin{array}{l}\text { Global Journal of Medical } \\
\text { Research }\end{array}$ & $\begin{array}{l}\text { Mohiuddin AK. Skin Aging \& Modern Age Anti-aging } \\
\text { Strategies. Global Journal of Medical Research, } 19 \text { Issue } 2 \\
\text { Version 1.0 Year } 2019 \text { Page } 15-60\end{array}$ \\
\hline 42. & $\begin{array}{l}\text { Safety Issues of Biosimilar } \\
\text { Products }\end{array}$ & $\begin{array}{l}\text { Journal of Cancer Research } \\
\text { and Therapeutic Oncology } \\
\text { (JCRTO) }\end{array}$ & $\begin{array}{l}\text { Abdul Kader Mohiuddin (2019) Safety Issues of Biosimilar } \\
\text { Products. J Cancer Res Therap Oncol 7:1-4. } \\
\text { DOI:10.17303/jcrto.2019.7.105 }\end{array}$ \\
\hline 43. & $\begin{array}{l}\text { Environmental Factors on } \\
\text { Secondary Metabolism of } \\
\text { Medicinal Plants. }\end{array}$ & $\begin{array}{l}\text { Acta Scientific } \\
\text { Pharmaceutical Sciences }\end{array}$ & $\begin{array}{l}\text { Mohi Uddin. "Environmental Factors on Secondary } \\
\text { Metabolism of Medicinal Plants". Acta Scientific } \\
\text { Pharmaceutical Sciences } 3.8 \text { (2019): } 34-46 .\end{array}$ \\
\hline 44. & $\begin{array}{l}\text { Modern Age Cosmetics: An } \\
\text { Extensive Review }\end{array}$ & $\begin{array}{l}\text { Research and Advances in } \\
\text { Pharmacy and Life Sciences }\end{array}$ & $\begin{array}{l}\text { Mohiuddin AK. Modern Age Cosmetics: An Extensive } \\
\text { Review. Research and Advances in Pharmacy and Life } \\
\text { Sciences Vol 1, Issue 2, Page 47-92. DOI: } \\
\text { http://doi.org/10.5281/zenodo.3333365 }\end{array}$ \\
\hline 45. & $\begin{array}{l}\text { Alternative Treatments for } \\
\text { Minor GI Ailments }\end{array}$ & $\begin{array}{l}\text { INNOVATIONS in } \\
\text { pharmacy }\end{array}$ & $\begin{array}{l}\text { Mohiuddin AK. Alternative Treatments for Minor GI } \\
\text { Ailments. INNOVATIONS in pharmacy Vol 10, No 3, } \\
\text { (2019)/ Insights. DOI: } \\
\text { https://doi.org/10.24926/iip.v10i3.1659 }\end{array}$ \\
\hline 46. & $\begin{array}{l}\text { Domination of gastric } \\
\text { Complications Among } \\
\text { Diabetic Patients }\end{array}$ & $\begin{array}{l}\text { Biomedical Journal of } \\
\text { Technical \& Scientific } \\
\text { Research }\end{array}$ & $\begin{array}{l}\text { Abdul Kader Mohiuddin. Domination of gastric } \\
\text { Complications Among Diabetic Patients. Biomed J Sci \& } \\
\text { Tech Res 19(4)-2019. BJSTR. MS.ID.003331. DOI: } \\
\text { 10.26717/BJSTR.2019.19.003331 }\end{array}$ \\
\hline 47. & $\begin{array}{l}\text { Safety Issues of Biosimilar } \\
\text { Products }\end{array}$ & $\begin{array}{l}\text { Advances in Clinical } \\
\text { Toxicology } \\
\text { (ISSN: } 2577-4328 \text { ) }\end{array}$ & $\begin{array}{l}\text { Mohiuddin AK. Safety Issues of Biosimilar Products. Adv } \\
\text { Clin Toxicol 2019, 4(3):000158. DOI: 10.23880/act- } \\
16000158\end{array}$ \\
\hline
\end{tabular}




\begin{tabular}{|c|c|c|c|}
\hline 48. & $\begin{array}{l}\text { An Extensive Review on } \\
\text { Sunscreen and Suntan } \\
\text { Preparations }\end{array}$ & $\begin{array}{l}\text { OSP Journal of Clinical } \\
\text { Trials }\end{array}$ & $\begin{array}{l}\text { Mohiuddin AK (2019) An Extensive Review on Sunscreen } \\
\text { and Suntan Preparations. OSP J Clin Trials. Volume 1, Issue } \\
\text { 1, Page 1-25: JCT-1-105 }\end{array}$ \\
\hline 49. & $\begin{array}{l}\text { Nutritional Value and } \\
\text { Associated Potentials Risks of } \\
\text { Seafood Consumption }\end{array}$ & $\begin{array}{l}\text { Advances in Clinical } \\
\text { Toxicology ISSN: } 2577 \text { - } \\
4328\end{array}$ & $\begin{array}{l}\text { Mohiuddin AK. Nutritional Value and Associated Potentials } \\
\text { Risks of Seafood Consumption. Adv Clin Toxicol 2019, } \\
\text { 4(3): 000159. DOI: } 10.23880 / \text { act-16000159 }\end{array}$ \\
\hline 50. & $\begin{array}{l}\text { Cost of Biotech Drug } \\
\text { Development and } \\
\text { Affordability Issues in LMICs }\end{array}$ & $\begin{array}{l}\text { Archives in Biomedical } \\
\text { Engineering \& } \\
\text { Biotechnology }\end{array}$ & $\begin{array}{l}\text { Abdul Kader Mohiuddin. Cost of Biotech Drug Development } \\
\text { and Affordability Issues in LMICs. Arch Biomed Eng \& } \\
\text { Biotechnol. 2(3): 2019. DOI: } \\
\text { 10.33552/ABEB.2019.02.000538. }\end{array}$ \\
\hline 51. & $\begin{array}{l}\text { Psychiatric Pharmacy: New } \\
\text { Role of Pharmacists in Mental } \\
\text { Health }\end{array}$ & $\begin{array}{l}\text { Scholarly Journal of } \\
\text { Psychology } \\
\text { and Behavioral Sciences }\end{array}$ & $\begin{array}{l}\text { Abdul Kader Mohiuddin. Psychiatric Pharmacy: New Role } \\
\text { of Pharmacists in Mental Health. Sch J Psychol \& Behav Sci. } \\
\text { 2(4)-2019. SJPBS MS.ID.000144. DOI: } \\
\text { 10.32474/SJPBS.2019.02.000144. }\end{array}$ \\
\hline 52. & $\begin{array}{l}\text { Chemistry of Secondary } \\
\text { Metabolites }\end{array}$ & $\begin{array}{l}\text { Annals of Clinical } \\
\text { Toxicology }\end{array}$ & $\begin{array}{l}\text { Mohiuddin AK. Chemistry of Secondary Metabolites. Ann } \\
\text { Clin Toxicol. 2019; 2(1): 1014. DOI: } \\
\text { http://dx.doi.org/10.25107/2641-905X-v2-id1014 }\end{array}$ \\
\hline 53. & $\begin{array}{l}\text { Acne Protection: Measures \& } \\
\text { Miseries }\end{array}$ & $\begin{array}{l}\text { Annals of Clinical } \\
\text { Toxicology }\end{array}$ & $\begin{array}{l}\text { Mohiuddin AK. Acne Protection: Measures \& Miseries. Ann } \\
\text { Clin Toxicol. 2019; 2(2): 1017. } \\
\text { http://dx.doi.org/10.25107/2641-905X-v2-id1017 }\end{array}$ \\
\hline 54. & $\begin{array}{l}\text { The Mysterious Domination } \\
\text { of Food/Drinking Water } \\
\text { Contaminants and Adulterants } \\
\text { in Bangladesh }\end{array}$ & $\begin{array}{l}\text { Agriculture and Food } \\
\text { Sciences Research }\end{array}$ & $\begin{array}{l}\text { Mohiuddin, A. K. "The Mysterious Domination of } \\
\text { Food/Drinking Water Contaminants and Adulterants in } \\
\text { Bangladesh". Agriculture and Food Sciences Research, Vol. } \\
\text { 6, no. 1, June 2019, pp. 30-40, } \\
\text { doi:10.20448/journal.512.2019.61.30.40. }\end{array}$ \\
\hline 55. & $\begin{array}{l}\text { Getting Rid of "Bomb } \\
\text { Pushing the Womb": } \\
\text { Dysmenorrhea Management }\end{array}$ & $\begin{array}{l}\text { Journal of Gynecology and } \\
\text { Women's Health }\end{array}$ & $\begin{array}{l}\text { Abdul Kader Mohiuddin. Getting Rid of "Bomb Pushing the } \\
\text { Womb": Dysmenorrhea Management. J Gynecol Women's } \\
\text { Health. 2019: 16(1): 555929. DOI: } \\
\text { 10.19080/JGWH.2019.14.555929 }\end{array}$ \\
\hline 56. & $\begin{array}{l}\text { Arts and Science of Athletic } \\
\text { Performance }\end{array}$ & $\begin{array}{l}\text { Internal Journal of Sports } \\
\text { Medicine and Rehabilitation }\end{array}$ & $\begin{array}{l}\text { Abdul Kader Mohiuddin. Arts and Science of Athletic } \\
\text { Performance. Internal Journal of Sports Medicine and } \\
\text { Rehabilitation, 2019;2:8 }\end{array}$ \\
\hline 57. & $\begin{array}{l}\text { Heavy Metals: The Notorious } \\
\text { Daredevils of Daily Personal } \\
\text { Care Products }\end{array}$ & $\begin{array}{l}\text { International Journal of } \\
\text { Pharmacy and } \\
\text { Pharmacology Research }\end{array}$ & $\begin{array}{l}\text { Abdul Kader Mohiuddin (2019). Heavy Metals: The } \\
\text { Notorious Daredevils of Daily Personal Care Products. } \\
\text { IJPPR 2(1).008-018. DOI: 10.14412/IJPPR2019.018 }\end{array}$ \\
\hline 58. & $\begin{array}{l}\text { Sunscreen and coral reef } \\
\text { (Letter to the editor) }\end{array}$ & $\begin{array}{l}\text { MOJ Ecology \& } \\
\text { Environmental Sciences }\end{array}$ & $\begin{array}{l}\text { Mohiuddin AK. Sunscreen and coral reef: letter to the editor. } \\
\text { MOJ Eco Environ Sci. 2019;4(4):166 - 167. DOI: } \\
\text { 10.15406/mojes.2019.04.00149 }\end{array}$ \\
\hline 59. & $\begin{array}{l}\text { Supplements and } \\
\text { Enhancement Drugs: Athletes } \\
\text { Torment Themselves with } \\
\text { Potential Risks. }\end{array}$ & $\begin{array}{l}\text { International Journal of } \\
\text { Pharmacy and } \\
\text { Pharmacology Research }\end{array}$ & $\begin{array}{l}\text { Abdul Kader Mohiuddin (2019). Supplements and } \\
\text { Enhancement Drugs: Athletes Torment Themselves with } \\
\text { Potential Risks. IJPPR 2(1).019-025. DOI: } \\
\text { 10.14412/IJPPR2019.025 }\end{array}$ \\
\hline 60. & $\begin{array}{l}\text { Patient Safety: A Deep } \\
\text { Concern to Caregivers }\end{array}$ & $\begin{array}{l}\text { INNOVATIONS in } \\
\text { pharmacy }\end{array}$ & $\begin{array}{l}\text { Mohiuddin AK. Patient Safety: A Deep Concern to } \\
\text { Caregivers. INNOVATIONS in pharmacy Vol } 10 \text { No } 1 \\
\text { (2019) pp 1-11. DOI: https://doi.org/10.24926/iip.v10i1.1639 }\end{array}$ \\
\hline 61. & $\begin{array}{l}\text { Cosmetics' Safety: Gray } \\
\text { Areas with Darker Inside }\end{array}$ & $\begin{array}{l}\text { American Research Journal } \\
\text { of Dermatology }\end{array}$ & $\begin{array}{l}\text { Abdul Kader Mohiuddin. "Cosmetics' Safety: Gray Areas } \\
\text { with Darker Inside". American Research Journal of } \\
\text { Dermatology; 1(1): 1-7. http://dx.doi.org/10.21694/2642- } \\
2980.19006\end{array}$ \\
\hline 62. & $\begin{array}{l}\text { Urbanization, Environmental } \\
\text { Pollution \& Skin Aging }\end{array}$ & $\begin{array}{l}\text { American Research Journal } \\
\text { of Dermatology }\end{array}$ & $\begin{array}{l}\text { Abdul Kader Mohiuddin. "Urbanization, Environmental } \\
\text { Pollution \& Skin Aging". American Research } \\
\text { Journal of Dermatology; 1(1): 1-9. } \\
\text { http://dx.doi.org/10.21694/2642-2980.19007 }\end{array}$ \\
\hline 63. & $\begin{array}{l}\text { Patient Relationship } \\
\text { Management: Patient Care } \\
\text { with CRM Approach }\end{array}$ & PharmaTutor & $\begin{array}{l}\text { Mohiuddin, A. 2019. "Patient Relationship Management: } \\
\text { Patient Care With CRM Approach". PharmaTutor } 7 \text { (4), 22- } \\
\text { 36. https://doi.org/10.29161/PT.v7.i4.2019.22. }\end{array}$ \\
\hline 64. & $\begin{array}{l}\text { Pharmacists in Ambulatory/ } \\
\text { Outpatient Care }\end{array}$ & $\begin{array}{l}\text { Journal of Pharmacology \& } \\
\text { Clinical Research } \\
\text { ISSN: 2473-5574 }\end{array}$ & $\begin{array}{l}\text { AK Mohiuddin. Pharmacists in Ambulatory/ Outpatient } \\
\text { Care. J of Pharmacol \& Clin Res. 2019; 7(1): 555701. DOI: } \\
\text { 10.19080/JPCR.2019.07.555701 }\end{array}$ \\
\hline 65. & $\begin{array}{l}\text { Patient Care Management } \\
\text { (Book Review) }\end{array}$ & $\begin{array}{l}\text { Lupine Online Journal of } \\
\text { Nursing \& Health care }\end{array}$ & $\begin{array}{l}\text { Abdul Kader Mohiuddin. Patient Care Management. LOJ } \\
\text { Nur Heal Car 2(5)- 2020. LOJNHC.MS.ID.000146. DOI: } \\
\text { 10.32474/LOJNHC.2020.02.000146. }\end{array}$ \\
\hline
\end{tabular}




\begin{tabular}{|c|c|c|c|}
\hline 66. & $\begin{array}{l}\text { Telepharmacy Service: } \\
\text { Contributions and } \\
\text { Controversies }\end{array}$ & $\begin{array}{l}\text { Journal of Public Health } \\
\text { and Disease Prevention }\end{array}$ & $\begin{array}{l}\text { Abdul Kader M (2019) Telepharmacy Service: Contributions } \\
\text { and Controversies. J Public Health Dis Prev 2: } 201\end{array}$ \\
\hline 67. & $\begin{array}{l}\text { Heavy Metals in Cosmetics: } \\
\text { The Notorious Daredevils and } \\
\text { Burning Health Issues }\end{array}$ & $\begin{array}{l}\text { American Journal of } \\
\text { Biomedical Science \& } \\
\text { Research }\end{array}$ & $\begin{array}{l}\text { Abdul Kader Mohiuddin. Heavy Metals in Cosmetics: The } \\
\text { Notorious Daredevils and Burning Health Issues. Am J } \\
\text { Biomed Sci \& Res. } 2019 \text { - 4(5). AJBSR.MS.ID.000829. } \\
\text { DOI: 10.34297/AJBSR.2019.04.000829 }\end{array}$ \\
\hline 68. & $\begin{array}{l}\text { Community Liaison } \\
\text { Pharmacists In Home Care }\end{array}$ & PharmaTutor & $\begin{array}{l}\text { Mohiuddin, A. 2019. Community Liaison Pharmacists in } \\
\text { Home Care. PharmaTutor. 7, } 4 \text { (Apr. 2019), 1-21. DOI: } \\
\text { https://doi.org/10.29161/PT.v7.i4.2019.1. }\end{array}$ \\
\hline 69. & $\begin{array}{l}\text { Comparison of Drug and Non- } \\
\text { Drug Treatment Options of } \\
\text { Fibromyalgia }\end{array}$ & $\begin{array}{l}\text { Global Journal of } \\
\text { Orthopedics Research }\end{array}$ & $\begin{array}{l}\text { Abdul Kader Mohiuddin. Comparison of Drug and Non- } \\
\text { Drug Treatment Options of Fibromyalgia Glob J Ortho Res. } \\
\text { 1(5): 2019. GJOR. MS.ID.000522. DOI: } \\
\text { 10.33552/GJOR.2019.01.000522 }\end{array}$ \\
\hline 70. & $\begin{array}{l}\text { Domination of Pollutant } \\
\text { Residues among Food } \\
\text { Products of South-East Asian } \\
\text { Countries }\end{array}$ & $\begin{array}{l}\text { Global Journal of Nutrition } \\
\& \text { Food Science }\end{array}$ & $\begin{array}{l}\text { AK Mohiuddin. Domination of Pollutant Residues among } \\
\text { Food Products of South-East Asian Countries. Glob J Nutri } \\
\text { Food Sci. 2(3): 2019. GJNFS.MS.ID.000536. DOI: } \\
\text { 10.33552/GJNFS.2019.02.000536. }\end{array}$ \\
\hline 71. & $\begin{array}{l}\text { Skipping Breakfast Everyday } \\
\text { Keeps Well-being Away }\end{array}$ & $\begin{array}{l}\text { ACTA MEDICA (former } \\
\text { Hacettepe Medical Journal) }\end{array}$ & $\begin{array}{l}\text { Mohiuddin, A. "Skipping Breakfast Everyday Keeps Well- } \\
\text { Being Away". Acta Medica, Vol. 50, no. 1, Mar. 2019, pp. } \\
\text { 26-33, doi:10.32552/2019.ActaMedica.331. }\end{array}$ \\
\hline 72. & $\begin{array}{l}\text { Fast Food: "The Real Costs } \\
\text { Never Appears on the Menu" }\end{array}$ & $\begin{array}{l}\text { Journal of Public Health } \\
\text { and Disease Prevention }\end{array}$ & $\begin{array}{l}\text { Mohiuddin AK (2019) Fast Food: "The Real Costs Never } \\
\text { Appears on the Menu". J Public Health Dis Prev 2: } 204\end{array}$ \\
\hline 73. & $\begin{array}{l}\text { Pharmacist-Patient } \\
\text { Relationship: Commitment to } \\
\text { Care (Editorial) }\end{array}$ & $\begin{array}{l}\text { Biomedical Journal of } \\
\text { Technical \& Scientific } \\
\text { Research }\end{array}$ & $\begin{array}{l}\text { Abdul Kader Mohiuddin. Pharmacist-Patient Relationship: } \\
\text { Commitment to Care. Biomed J Sci \& Tech Res 21(1)-2019. } \\
\text { BJSTR. MS.ID.003549. DOI: } \\
\text { 10.26717/BJSTR.2019.21.003549 }\end{array}$ \\
\hline 74. & $\begin{array}{l}\text { Patient Medical History \& } \\
\text { Medical Record Keeping: } \\
\text { Accurate Problem } \\
\text { Identification For Effective } \\
\text { Solution (Review Article) }\end{array}$ & $\begin{array}{l}\text { ASIO Journal of Medical \& } \\
\text { Health Sciences Research }\end{array}$ & $\begin{array}{l}\text { Mohiuddin AK. Patient Medical History \& Medical Record } \\
\text { Keeping: Accurate Problem Identification For Effective } \\
\text { Solution. ASIO Journal of Medical \& Health Sciences } \\
\text { Research Volume 3, Issue 1, 2019, 18-31. http://doi- } \\
\text { ds.org/doilink/08.2019-26276391/ }\end{array}$ \\
\hline 75. & $\begin{array}{l}\text { Stress and Complicacy } \\
\text { Among Relationships: A } \\
\text { Major Health Concern }\end{array}$ & $\begin{array}{l}\text { International Research } \\
\text { Journal of Public Health }\end{array}$ & $\begin{array}{l}\text { Abdul Kader Mohiuddin. Stress and Complicacy Among } \\
\text { Relationships: A Major Health Concern. International } \\
\text { Research Journal of Public Health, 2020; 4:41 }\end{array}$ \\
\hline 76. & $\begin{array}{l}\text { Fast Food Addiction: A Major } \\
\text { Public Health Issue }\end{array}$ & ARC Journal of Addiction & $\begin{array}{l}\text { Abdul Kader Mohiuddin, Fast Food Addiction: A Major } \\
\text { Public Health Issue. ARC Journal of Addiction. 2019; } \\
\text { 4(2):1-11. }\end{array}$ \\
\hline 77. & $\begin{array}{l}\text { UTI prevalence among } \\
\text { population with chronic } \\
\text { conditions }\end{array}$ & $\begin{array}{l}\text { International Journal of } \\
\text { Pharmacology and } \\
\text { Pharmaceutical Research }\end{array}$ & $\begin{array}{l}\text { Mohiuddin AK. UTI prevalence among population with } \\
\text { chronic conditions. International Journal of Pharmacology } \\
\text { and Pharmaceutical Research. 2020;1(1):14-24. }\end{array}$ \\
\hline 78. & $\begin{array}{l}\text { TRACK Implementation: A } \\
\text { Bangladesh Scenario }\end{array}$ & $\begin{array}{l}\text { Central Asian Journal of } \\
\text { Global Health }\end{array}$ & $\begin{array}{l}\text { Mohiuddin AK. TRACK Implementation: a Bangladesh } \\
\text { Scenario. Central Asian Journal of Global Health. 2020;9(1). } \\
\text { doi:10.5195/cajgh.2020.416 }\end{array}$ \\
\hline 79. & $\begin{array}{l}\text { The Excellence of Pharmacy } \\
\text { Service: Past, Present and } \\
\text { Future }\end{array}$ & $\begin{array}{l}\text { International Journal of } \\
\text { Clinical and Developmental } \\
\text { Anatomy }\end{array}$ & $\begin{array}{l}\text { A. K. Mohiuddin, The Excellence of Pharmacy Service: Past, } \\
\text { Present and Future, International Journal of Clinical and } \\
\text { Developmental Anatomy. Vol. 5, No. 2, 2019, pp. 15-36. } \\
\text { doi: } 10.11648 / j . i j c d a .20190502 .12\end{array}$ \\
\hline 80. & $\begin{array}{l}\text { Health Hazards with } \\
\text { Adulterated Spices: Save the } \\
\text { "Onion Tears" }\end{array}$ & $\begin{array}{l}\text { Asian Journal of Research } \\
\text { in Pharmaceutical Sciences }\end{array}$ & $\begin{array}{l}\text { Abdul Kader Mohiuddin. Health Hazards with Adulterated } \\
\text { Spices: Save the "Onion Tears". Asian J. Res. Pharm. Sci. } \\
\text { 2020; } 10(1): 21-25 \text {. DOI No: } 10.5958 / 2231 \text { - } \\
5659.2020 .00005 .3\end{array}$ \\
\hline 81. & $\begin{array}{l}\text { Patient Satisfaction: } \\
\text { Bangladesh Perspective }\end{array}$ & $\begin{array}{l}\text { International Research } \\
\text { Journal of Public Health }\end{array}$ & $\begin{array}{l}\text { Abdul Kader Mohiuddin. Patient Satisfaction: Bangladesh } \\
\text { Perspective. International Research Journal of Public Health, } \\
\text { 2019; 3:32. DOI:10.28933/irjph-2019-10-2805 }\end{array}$ \\
\hline 82. & $\begin{array}{l}\text { Dengue Protection and Cure: } \\
\text { Bangladesh Perspective }\end{array}$ & $\begin{array}{l}\text { European Journal of } \\
\text { Sustainable Development } \\
\text { Research }\end{array}$ & $\begin{array}{l}\text { Mohiuddin AK. Dengue Protection and Cure: Bangladesh } \\
\text { Perspective. EUROPEAN J SUSTAINAB DEV. 2020;4(1), } \\
\text { em0104. https://doi.org/10.29333/ejosdr/6260 }\end{array}$ \\
\hline 83. & $\begin{array}{l}\text { Dengue Epidemic Situation in } \\
\text { Bangladesh }\end{array}$ & $\begin{array}{l}\text { Journal of Clinical Case } \\
\text { Studies } \\
\text { ISSN 2471-4925 }\end{array}$ & $\begin{array}{l}\text { Mohiuddin AK (2019) Dengue Epidemic Situation in } \\
\text { Bangladesh. J Clin Case Stu 4(3): dx.doi.org/10.16966/2471- } \\
4925.193\end{array}$ \\
\hline 84. & $\begin{array}{l}\text { Alternative Measures for IBS } \\
\text { Management }\end{array}$ & Journal of & $\begin{array}{l}\text { Mohiuddin AK. Alternative Measures for IBS Management. } \\
\text { Journal of Gastroenterology and Hepatology Research 2019; }\end{array}$ \\
\hline
\end{tabular}




\begin{tabular}{|c|c|c|c|}
\hline & & $\begin{array}{l}\text { Gastroenterology and } \\
\text { Hepatology Research }\end{array}$ & $\begin{array}{l}\text { 8(6): 3025-332. DOI: } 10.17554 / \text { j.issn.2224- } \\
\text { 3992.2019.08.861 }\end{array}$ \\
\hline 85. & $\begin{array}{l}\text { Conventional and Alternative } \\
\text { Measures for IBS } \\
\text { Management }\end{array}$ & $\begin{array}{l}\text { Current Trends in } \\
\text { Gastroenterology and } \\
\text { Hepatology }\end{array}$ & $\begin{array}{l}\text { Abdul Kader M, M Nasirullah. Conventional and } \\
\text { Alternative Measures for IBS Management. Curr Tr Gatsr \& } \\
\text { Hepatol 2(5)- 2019. CTGH.MS.ID.000146. DOI: } \\
\text { 10.32474/CTGH.2019.02.000146. }\end{array}$ \\
\hline 86. & $\begin{array}{l}\text { Drug Addiction in } \\
\text { Bangladesh: "A Consequence } \\
\text { of Social Demoralization } \\
\text { Rather than Individual Flaws" }\end{array}$ & ARC Journal of Addiction & $\begin{array}{l}\text { Abdul Kader Mohiuddin, Drug Addiction in Bangladesh: } \\
\text { "A Consequence of Social Demoralization Rather than } \\
\text { Individual Flaws". ARC Journal of Addiction. 2019; 4(1):19- } \\
26 .\end{array}$ \\
\hline 87. & $\begin{array}{l}\text { Pharmacists in } \\
\text { Home/Hospice/Palliative Care } \\
\text { Settings }\end{array}$ & $\begin{array}{l}\text { International Journal of } \\
\text { Aging Research }\end{array}$ & $\begin{array}{l}\text { Abdul Kader Mohiuddin. Pharmacists in } \\
\text { Home/Hospice/Palliative Care Settings. International Journal } \\
\text { of Aging Research, 2019, 2:42. DOI: 10.28933/ijoar-2019- } \\
08-1006\end{array}$ \\
\hline 88. & $\begin{array}{l}\text { Pharmacists in Transition } \\
\text { Care }\end{array}$ & $\begin{array}{l}\text { Journal of pharmacology } \\
\text { and Clinical research }\end{array}$ & $\begin{array}{l}\text { AK Mohiuddin. Pharmacists in Transition Care. J of } \\
\text { Pharmacol \& Clin Res. 2019; 7(1): 555705. DOI: } \\
\text { 10.19080/JPCR.2019.07.555705 }\end{array}$ \\
\hline 89. & $\begin{array}{l}\text { Community and Clinical } \\
\text { Pharmacists in Transition } \\
\text { Care }\end{array}$ & $\begin{array}{l}\text { Global Journal of Pharmacy } \\
\text { \& Pharmaceutical Sciences } \\
\text { (GJPPS) ISSN: } 2573-2250\end{array}$ & $\begin{array}{l}\text { AK Mohiuddin. Community and Clinical Pharmacists in } \\
\text { Transition Care. Glob J Pharmaceu Sci. 2019; 7(2): } \\
\text { 555706. DOI:10.19080/GJPPS.2019.07.555706. }\end{array}$ \\
\hline 90. & The Critical Care Pharmacists & $\begin{array}{l}\text { Journal of Global } \\
\text { Biosciences }\end{array}$ & $\begin{array}{l}\text { The Critical Care Pharmacists. Journal of Global } \\
\text { Biosciences. 2019;8(1):5847-5869. doi: } \\
\text { https//mutagens.co.in/doi/v08i1.09. }\end{array}$ \\
\hline 91. & $\begin{array}{l}\text { Sunscreen and coral reef } \\
\text { (Letter to the editor) }\end{array}$ & $\begin{array}{l}\text { MOJ Ecology \& } \\
\text { Environmental Sciences } \\
\text { (eISSN: 2573-2919) }\end{array}$ & $\begin{array}{l}\text { Mohiuddin AK. Sunscreen and coral reef: letter to the editor. } \\
\text { MOJ Eco Environ Sci. 2019;4(4):166-167. DOI: } \\
\text { 10.15406/mojes.2019.04.00149 }\end{array}$ \\
\hline 92. & Framework for Patient Safety & PharmaTutor & $\begin{array}{l}\text { Mohiuddin AK. Framework for Patient Safety. PharmaTutor. } \\
\text { 2019;7(2):21. doi:10.29161/pt.v7.i2.2019.21 }\end{array}$ \\
\hline 93. & $\begin{array}{l}\text { An In-Depth of A Pharmacist } \\
\text { In Prescribing }\end{array}$ & $\begin{array}{l}\text { Journal of Applied } \\
\text { Pharmaceutical Sciences } \\
\text { and Research }\end{array}$ & $\begin{array}{l}\text { Mohiuddin AK. An In-Depth Of A Pharmacist In } \\
\text { Prescribing. Journal of Applied Pharmaceutical Sciences and } \\
\text { Research. 2019;1(4):11-18. doi:10.31069/japsr.v1i4.2 }\end{array}$ \\
\hline 94. & $\begin{array}{l}\text { Medication Risk } \\
\text { Management: A Subjective } \\
\text { Review of Present Scenario }\end{array}$ & $\begin{array}{l}\text { Journal of Pharma and Drug } \\
\text { Regulatory Affairs }\end{array}$ & $\begin{array}{l}\text { AK Mohiuddin. Medication Risk Management: A Subjective } \\
\text { Review of Present Scenario. Journal of Pharma and Drug } \\
\text { Regulatory Affairs. 2019;1(1):38-62. } \\
\text { doi:10.5281/zenodo.2590031. }\end{array}$ \\
\hline 95. & $\begin{array}{l}\text { An Extensive Review of } \\
\text { Patient Satisfaction with } \\
\text { Healthcare Services in } \\
\text { Bangladesh }\end{array}$ & $\begin{array}{l}\text { Patient Experience Journal } \\
\text { (The Beryl Institute, } \\
\text { Nashville, US) }\end{array}$ & $\begin{array}{l}\text { Mohiuddin AK. An extensive review of patient satisfaction } \\
\text { with healthcare services in Bangladesh services in } \\
\text { Bangladesh. Patient Experience Journal. 2020;7(2):59-71. } \\
\text { doi:10.35680/2372-0247.1415 }\end{array}$ \\
\hline 96. & $\begin{array}{l}\text { Prospect of Tele-Pharmacists } \\
\text { in Pandemic Situations: } \\
\text { Bangladesh Perspective }\end{array}$ & $\begin{array}{l}\text { European Journal of } \\
\text { Clinical and Experimental } \\
\text { Medicine }\end{array}$ & $\begin{array}{l}\text { Mohiuddin AK. Prospect of Tele-Pharmacists in Pandemic } \\
\text { Situations: Bangladesh Perspective. Eur J Clin Exp Med. } \\
\text { 2020;18(2):101-109. doi: 10.15584/ejcem.2020.2.4 }\end{array}$ \\
\hline 97. & $\begin{array}{l}\text { Covid-19 Situation in } \\
\text { Bangladesh }\end{array}$ & Preprints (MDPI) & $\begin{array}{l}\text { Mohiuddin, A.K. Covid-19 Situation in Bangladesh. } \\
\text { Preprints 2020, 2020050094 (doi: } \\
\text { 10.20944/preprints202005.0094.v1). }\end{array}$ \\
\hline 98. & $\begin{array}{l}\text { An Extensive Review of } \\
\text { Health and Economy of } \\
\text { Bangladesh Amid Covid-19 } \\
\text { Pandemic }\end{array}$ & $\begin{array}{l}\text { International Journal of } \\
\text { Reviews and Research in } \\
\text { Social Sciences }\end{array}$ & $\begin{array}{l}\text { Abdul Kader Mohiuddin. An Extensive Review of Health } \\
\text { and Economy of Bangladesh Amid Covid-19 Pandemic. Int. } \\
\text { J. Rev. and Res. Social Sci. 2020; 8(2):108-117. doi: } \\
\text { 10.5958/2454-2687.2020.00011.8 }\end{array}$ \\
\hline 99. & $\begin{array}{l}\text { COVID-19 and } 20 \\
\text { Resolutions for Bangladesh }\end{array}$ & $\begin{array}{l}\text { European Journal of } \\
\text { Sustainable Development } \\
\text { Research }\end{array}$ & $\begin{array}{l}\text { Mohiuddin AK. COVID-19 and } 20 \text { Resolutions for } \\
\text { Bangladesh. European Journal of Sustainable Development } \\
\text { Research. 2020;4(4). doi: 10.29333/ejosdr/8433 }\end{array}$ \\
\hline 100. & $\begin{array}{l}\text { Phytochemical Screening \& } \\
\text { Biological Investigations of } \\
\text { Ficus Racemosa }\end{array}$ & $\begin{array}{l}\text { Open Access Journal of } \\
\text { Biogeneric Science and } \\
\text { Research }\end{array}$ & $\begin{array}{l}\text { Abdul Kader Mohiuddin*, Sayra Akter Lia, Phytochemical } \\
\text { Screening \& Biological Investigations of Ficus Racemosa. } \\
\text { Op Acc J Bio Sci \& Res 4(1)-2020. DOI: } \\
\text { 10.46718/JBGSR.2020.03.000088 }\end{array}$ \\
\hline
\end{tabular}

Table 4. Author's Published Articles

\begin{tabular}{|c|l|l|l|}
\hline No. & Publication & Journal & Citation \\
\hline 1. & $\begin{array}{l}\text { নীরব ঘাতক ডায়াবেটিস: বাংলাদেশে } \\
\text { বর্তমান পরিস্থিতি }\end{array}$ & দৈনিক সিএন বাংলা & $\begin{array}{l}\text { আব্দুল কাদের মহিউদ্দিন. নীরব ঘাতক ডায়াবেটিস: বাংলাদেশে বর্তমান পরিস্থিতি. } \\
\text { দৈনিক সিএন বাংলা /স্বাস্থ্য ও জীবন, জুলাই ১৯, ২০২০. } \\
\text { https://www.dailycnbangla.com/print?id=1080 }\end{array}$ \\
\hline
\end{tabular}




\begin{tabular}{|c|c|c|c|}
\hline 2. & কোভিড -১৯ এবং ২০টি সমাধান & আজ সারাবেলা & $\begin{array}{l}\text { আব্দুল কাদের মহিউদ্দিন. কোভিড -১৯ এবং ২০ টি সমাধান. আজ সারাবেলা/ মত } \\
\text { প্রকাশ, জুন ১, ২০২০. Available in: } \\
\text { https://www.ajsarabela.com/2020/06/01/কোভিড-১৯-এবং-২০-টি- } \\
\text { সমাধান.html }\end{array}$ \\
\hline 3. & মহামারী পরিস্থিতিতে টেলিফার্মানি & আজ সারাবেলা & $\begin{array}{l}\text { আব্দুল কাদের মহিউদ্দিন. মহামারী পরিস্থিতিতে টেলিফার্মাসি. আজ সারাবেলা/ মত } \\
\text { প্রকাশ, নে ১৫, ২০২০. Available in: } \\
\text { https://www.ajsarabela.com/2020/05/15/মহামারী-পরিস্থিতিতে- } \\
\text { টেলি.html }\end{array}$ \\
\hline 4. & $\begin{array}{l}\text { Drug addiction, a } \\
\text { consequence of social ills } \\
\text { rather than individual flaws }\end{array}$ & The Independent & $\begin{array}{l}\text { Abdul kader Mohiuddin. Drug addiction, a consequence of } \\
\text { social ills rather than individual flaws. The } \\
\text { Independent/Editorial, } 27 \text { November, } 2019 .\end{array}$ \\
\hline 5. & $\begin{array}{l}\text { Drug addiction: Causes and } \\
\text { consequences }\end{array}$ & The Independent & $\begin{array}{l}\text { Abdul kader Mohiuddin. Drug addiction: Causes and } \\
\text { consequences. The Independent/Editorial, } 4 \text { December, } 2019 .\end{array}$ \\
\hline 6. & $\begin{array}{l}\text { Public health: Chemical } \\
\text { residues in food grains }\end{array}$ & The Independent & $\begin{array}{l}\text { Mohiuddin AK. Public health: Chemical residues in food } \\
\text { grains. The Independent (OP-ED), } 30 \text { August, } 2019 .\end{array}$ \\
\hline 7. & $\begin{array}{l}\text { Risk-benefit issues of seafood } \\
\text { consumption }\end{array}$ & The Independent & $\begin{array}{l}\text { AK Mohiuddin. Risk-benefit issues of seafood consumption. } \\
\text { The Independent, Op-ed, } 19 \text { September, 2019. Available in: } \\
\text { http://www.theindependentbd.com/printversion/details/21596 } \\
6\end{array}$ \\
\hline 8. & $\begin{array}{l}\text { The diabetes TRACK and the } \\
\text { track records }\end{array}$ & The Independent & $\begin{array}{l}\text { AK Mohiuddin. The diabetes TRACK and the track records. } \\
\text { The Independent, Op-ed, } 02 \text { November, 2019. Available in: } \\
\text { http://www.theindependentbd.com/printversion/details/22202 } \\
6\end{array}$ \\
\hline 9. & $\begin{array}{l}\text { Health hazards with } \\
\text { adulterated spices: Save the } \\
\text { 'onion tears' }\end{array}$ & The Independent & $\begin{array}{l}\text { Abdul Kader Mohiuddin. Health hazards with adulterated } \\
\text { spices: Save the 'onion tears. The Independent (Op-ed), } 22 \\
\text { November, } 2019\end{array}$ \\
\hline 10. & $\begin{array}{l}\text { In search of an effective } \\
\text { programme for dengue } \\
\text { prevention }\end{array}$ & The Independent & $\begin{array}{l}\text { AK Mohiuddin. In search of an effective programme for } \\
\text { dengue prevention. The Independent, } 04 \text { September, } 2019 .\end{array}$ \\
\hline
\end{tabular}

Table 5. Published Articles in Printed/Online Newspapers

\section{Conclusion}

Universal-Publishers seeks authors who are experts in their field, and whose work addresses a specialized audience. Their mission is to expose new ideas and important scholarship. In exchange for distribution rights, they offer major distribution, fair compensation, multiple media editions, and personal attention. The esteem book was under editing and improvisation from the beginning of year 2019, after copyright agreement signing. The book is eligible to provide learning to both Pharmacy apprentices (mainstream and diploma pharmacists) for their regular courses related to Hospital and Community Pharmacy, Pharmacy Compounding and Dispensing as well as to the allied health professionals who are close to patients in their day-to-day activities. Major limitation of the book lies with the continuous improvement in different aspect of healthcare services around the world that cannot be detailed in a single frame. However, further reading references are given so that a reader can have an idea of sources that can benefit their future learnings. Also, a comparison table is added in Annexure 26 of the said book (Table 2 of the article), showing a few points that makes the book superior to similar other available books, which is further mentioned that those books obviously have their unique superiority over this book, The Role of the Pharmacist in Patient Care (Achieving High Quality, Cost-Effective and Accessible Healthcare Through a Team-Based, Patient-Centered Approach) in terms of their focus on respective subject matter(s). The book solely claims its superiority in terms of focus in detailing Pharmacists' major roles and responsibilities in patient care.

Web:https://www.universalpublishers.com/m/book.php?method=ISBN\&book=1627343083

\section{Amazon link:}

https://www.amazon.com/exec/obidos/ASIN/1627343083/ref=nosim/dis sertationcomd

\section{Barnes \& Noble:}

https://www.barnesandnoble.com/w/the-role-of-the-pharmacist-inpatient-care-abdul-kader-mohiuddin/1137309577

\section{Sample Chapter:}

https://www.docdroid.net/HPCzPeD/sample-chapter-patient-care-pdf

List of Contents (with sub-headings)

https://www.docdroid.net/WmUgghH/chapter-contents-docx

\section{Author Profile:}

https://www.researchgate.net/profile/Abdul_Kader_Mohiuddin

\section{PubMed Link:}

https://www.ncbi.nlm.nih.gov/nlmcatalog/101766397

NLM ID: 101766397 [Book]

\section{Acknowledgement}

I am grateful to the whole team of Universal Publishers, including Dr. Jeff Young (publisher and CEO) who helped \& guided with their team members for all their support to the work in this project and make this book project a success. I would like to pay thanks to Dr. Arinze Nkemdirim Okere, Associate Professor of Pharmacy, Clinical and Administrative Sciences, Florida A\&M University, USA and Dr. Mamun 
Rashid of Appalachian College of Pharmacy Oakwood, Virginia, USA for their precious time to review my manuscript and continued inspiration.

\section{References}

1. Boyce EG. (2017). The Pharmacists' Patient Care Process and More. Am J Pharm Educ. 81(4):62 doi:10.5688/ajpe81462

2. Dalton K, Byrne S. (2017). Role of the pharmacist in reducing healthcare costs: current insights. Integr Pharm Res Pract. 6:3746. Published doi:10.2147/IPRP.S108047

3. AK Mohiuddin. Clinical Pharmacists in Chronic Care Management. Academic Publications, India, 2019. E-BOOK ISBN:978-81-943354-0-5.

4. Abdul Kader M (2019). Telepharmacy Service: Contributions and Controversies. J Public Health Dis Prev 2: 201

5. Abdul Kader Mohiuddin. (2019). "ADRs and Clinical Toxicology". Acta Scientific Dental Sciences Special Issue 1 03-04. DOI: 10.31080/ASPS.2019.01.0002
6. Tsuyuki RT, Beahm NP, Okada H, Al Hamarneh YN. (2018). Pharmacists as accessible primary health care providers: Review of the evidence. Can Pharm J (Ott). 151(1):4-5. Published 2018 Jan 2. doi:10.1177/1715163517745517

7. Abdul Kader Mohiuddin. (2019). Pharmacist-Patient Relationship: Commitment to Care. Biomed J Sci \& Tech Res 21(1). BJSTR. MS.ID.003549. DOI:10.26717/BJSTR.2019.21.003549

8. Mohiuddin AK.(2019). Psychiatric Pharmacy: New Role of Pharmacists in Mental Health. J Psychiatry Mental Disord. 4(1): 1010

9. Karampatakis GD, Ryan K, Patel N, Stretch G. (2019) Capturing pharmacists' impact in general practice: an e-Delphi study to attempt to reach consensus amongst experts about what activities to record. BMC Fam Pract. 2019;20(1):126. Published. doi:10.1186/s12875-019-1008-6

10. Mohiuddin AK. (2018). An In-depth of Pharmacist in Prescribing. Journal of Applied Pharmaceutical Sciences and Research. 1(4): 11-18. DOI: 10.31069/japsr.v1i4.2
This work is licensed under Creative Commons Attribution 4.0 License

To Submit Your Article Click Here: Submit Manuscript

DOI: $10.31579 / 2690-8816 / 031$
Ready to submit your research? Choose Auctores and benefit from:

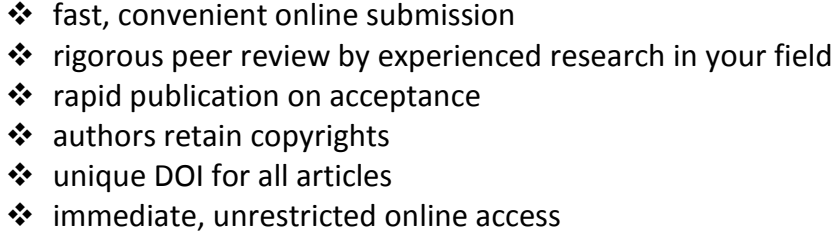

At Auctores, research is always in progress.

Learn more www.auctoresonline.org/journals/clinical-research-notes- 